\title{
A Study on the Flexural Behaviour of Geopolymer Lightweight Eco-Friendly Concrete Using Coconut Shell as Coarse Aggregate
}

\author{
S. Nithya $\mathbb{D}^{1},{ }^{1}$ K. Gunasekaran $\mathbb{D}^{2},{ }^{2}$ and G. Sankar $\mathbb{D}^{3}$ \\ ${ }^{1}$ Department of Architecture, Measi Academy of Architecture, Affiliated to Anna University, New College, Royapettah 600014, \\ Chennai, Tamil Nadu, India \\ ${ }^{2}$ Department of Civil Engineering, College of Engineering and Technology, SRM Institute of Science and Technology, SRM Nagar, \\ Kattankulathur 603203, Kanchipuram, Chennai, Tamil Nadu, India \\ ${ }^{3}$ Department of Polymer Science, Affiliated to Madras University, University of Madras, Guindy Campus 600025, Chennai, \\ Tamil Nadu, India
}

Correspondence should be addressed to S. Nithya; nithya@measiarch.net

Received 9 February 2021; Revised 26 June 2021; Accepted 5 July 2021; Published 16 July 2021

Academic Editor: Cristoforo Demartino

Copyright (c) $2021 \mathrm{~S}$. Nithya et al. This is an open access article distributed under the Creative Commons Attribution License, which permits unrestricted use, distribution, and reproduction in any medium, provided the original work is properly cited.

This paper presents the flexural behaviour of concrete containing ground granulated blast furnace slag (GGBS) as a binder, manufactured sand (M-sand) as a fine aggregate, and coconut shell (CS) and crushed stone aggregate (CSA) as coarse aggregates. Alkaline activator sodium hydroxide with 10 molarity and sodium silicate were used in a weighing proportion of $1: 2.5$ to produce structural grade concrete. Out of 12 beams cast, 6 were used to study geopolymer coconut shell concrete (GPCSC) beam behaviour and 6 were used to study geopolymer conventional concrete (GPCC) beam behaviour. Data presented include cracking behaviour, ultimate moment capacitates, deflection behaviour, ductility ratio, and end rotation of the beam. Laboratory investigations show encouraging results, and it can be summarized that coconut shell has good potential as a coarse aggregate for the production of structural grade geopolymer lightweight coconut shell concrete.

\section{Introduction}

Infrastructure development plays a major role in the country's economic growth, but also it leads to greenhouse effects. For infrastructure development, concrete is the most consumed building material. Conversely, it has been doing a notable impact on climate due to its large volumes and the energy consumption in the production of cement clinker, which has led to greenhouse gas emissions [1]. To reduce this impact, many initiatives were taken at academic, industrial, and government levels. The efforts mainly focus on the development, design, and execution of green materials that produce less waste, uses fewer resources, and consume less energy. The main aspect in achieving sustainable construction is to completely eliminate the use of virgin material to produce concrete.

To overcome this problem, geopolymer concrete has been introduced which can completely eliminate ordinary
Portland cement (OPC) with byproducts such as fly ash (FA), palm oil fuel ash (POFA), ground granulated blast furnace slag (GGBS), coconut shell powder (CSP), metakaolin (MK), and water with an alkaline activator. To produce geopolymer concrete, fine and coarse aggregate can be used as conventional concrete (CC). Many alternatives have been identified in natural and artificial aggregates to provide a partial replacement of conventional aggregates which lead to lot of research in the past decades for lightweight concrete (LWC).

Geopolymer production process can be divided into two major steps. The first one is mixing the components in proper proportion depending on the strength needed which includes mixing of binder, fine aggregate, coarse aggregate, and alkaline activators. The second step is heat curing. The heat curing process generally changes the internal structure of the geopolymer significantly. A mix containing binders such as fly ash or other slowly reacting raw material binders 
requires heat treatment mainly to enhance the maturity of the geopolymers. But heat curing is not necessary for all binders. Especially for slag-rich, geopolymer composites achieve their desired properties within a few hours or days at room temperature without any heat. The overall mechanism of geopolymerisation is established by three major phases: (i) dissolution of aluminosilicate in a highly alkaline environment, (ii) coagulation and gelation of dissolved oxide minerals, and (iii) formation of the 3D network (aluminosilicate structures). The resulting chemical bond facilitates the three predominant structures found in the $3 \mathrm{D}$ aluminasilicate network. The predominant structures are poly sialate, poly sialate-siloxy, and poly sialate-disiloxo.

The use of geopolymer technology significantly reduces the carbon dioxide emissions resulting from the cement industry and it is a potential substitute for conventional concrete. The mineral polymers resulting from the reaction between the oxides of $\mathrm{Si}$ and $\mathrm{Al}$ in the presence of an alkali solution are referred to as geopolymer. The general formula for a geopolymer is given in the following equation:

$$
\mathrm{M}\left[\left(\mathrm{SiO}_{2}\right)_{\mathrm{z}} \mathrm{AlO}_{2}\right] \cdot w \mathrm{H}_{2} \mathrm{O}
$$

where $\mathrm{M}$ is an alkali cation (such as sodium $\left(\mathrm{Na}^{+}\right)$or potassium $\left.\left(\mathrm{K}^{+}\right)\right), z$ is 1,2 , or 3 , and $w$ is the number of moles of water $[2,3]$. Products such as FA, MK, and slag are the main sources of alumina silicate materials. The behaviour and properties of the geopolymer binder depend on many factors such as alkaline activator types and their compositions, as well as the chemical composition of the binder, its curing condition, and the water binder ratio used in the mix.

Many studies were done in the past two decades for partial and full replacement of natural river sand, for example, with sugarcane bagasse ash, slag limestone, quarry dust, and siliceous stone powder. It is epitomized that the quality is the major concern in using alternative material for fine aggregate which can be achieved using M-sand [4, 5].

Disposal of this abundantly available coconut shell (CS) generated from the coconut industries creates an undesirable effect on the land causing huge environmental impact. Due to its abundant availability in India, a lot of research is going on by using these CS as partial or full replacement of coarse aggregate since the unit weight of concrete produced with CS is smaller because of the unit mass of CS used in the mixture [6-15].

In the present work, a systematic study has been carried out to study the flexural behaviour of lightweight geopolymer coconut shell concrete (GPCSC) and the results were compared to the geopolymer conventional concrete (GPCC). Performance aspects, such as load-carrying capacity, crack width, ductility ratio, ultimate moments, deflections, strains, and end rotation of the beam different stages, were studied. The failure modes were also recorded for the beams. The paper compares the performance of lightweight geopolymer coconut shell concrete beams to conventional geopolymer concrete beams.

\section{Experimental Programme}

2.1. Constituent Materials. GGBS was used as a binder (a complete replacement for the cement) to accelerate the geopolymerisation reaction at ambient temperature. The chemical analysis of the GGBS (binder) was analysed by the $\mathrm{x}$-ray photoelectron spectroscopy (XPS) using ULVAC-PHI, Inc; Model: PHI5000 Version Probe III. The chemical composition of the used GGBS is shown in Table 1, which contains a sum of $\mathrm{CaO}, \mathrm{SiO}_{2}$, and $\mathrm{MgO}$ of around $82 \%$, which represents more than two-thirds of the mass of the binder (Table 1). Manufactured sand (M-sand) (locally bought) was used as a fine aggregate, conforming to zone II as per IS 383: 2016 and also as per ASTM C 778 [16, 17], with a fineness modulus of 2.7 and a specific gravity of 2.6.

A coarse aggregate (CS) with a nominal size of $12.5 \mathrm{~mm}$, crushed in a crusher machine with a fineness modulus of 6.1 and a specific gravity of 1.15, was used to prepare the lightweight geopolymer coconut shell concrete (GPCSC). The CS used were collected from a site near Erode, Tamil Nadu, India. Collected CS were crushed using crusher equipment. After crushing, the CS were sieved and passed through $12.5 \mathrm{~mm}$ sieves and used as coarse aggregates. The aggregates used in concrete can be wet, dry with a saturated surface, air-dried, or oven-dried, as in ACI 211.2-98 and ASTM C 127 [18, 19]. In the saturated surface dry (SSD) condition, the aggregate is saturated, and the surface is dry. To prepare the CS in the SSD condition, the CS was immersed in water for $24 \mathrm{~h}$ to prevent water absorption from occurring during the mixing process. Figure 1 shows the process of CS from raw to SSD. The chemical composition and mechanical properties of the ingredients used are shown in Table 1. For the control mix, CSA coarse aggregate of $12.5 \mathrm{~mm}$ nominal size with a fineness modulus of 7.1 and a specific gravity of 2.86 was used to prepare GPCC.

2.2. Alkaline Activator. A sodium silicate and sodium hydroxide solution were chosen as the alkaline activator to activate the source material. A sodium silicate solution with $\mathrm{Na}_{2} \mathrm{O}=14.7 \%, \mathrm{SiO}_{2}=29.4 \%$ and water $=55.9 \%$ by mass was used for the study. The sodium hydroxide pellets with $97 \%-$ $98 \%$ purity were mixed with water to make a solution at 10 molarity $(10 \mathrm{M})$ concentration. The sodium hydroxide solution was prepared in the laboratory $24 \mathrm{~h}$ before casting. The sodium hydroxide and sodium silicate solution were prepared in a weight proportion of $1: 2.5$ just before casting.

2.3. Mix Design. A minimum compressive strength of $30 \mathrm{MPa}$ at 28 days was fixed as a target strength expected from the concrete mixes used so that the developed GPCC and GPCSC could be used for both non-structural and structural elements without any hesitation in practical implementation. The ingredients were chosen based on the trial mix since the ACI and Indian Standard methods could 
TABLE 1: Chemical composition and mechanical properties of the materials used.

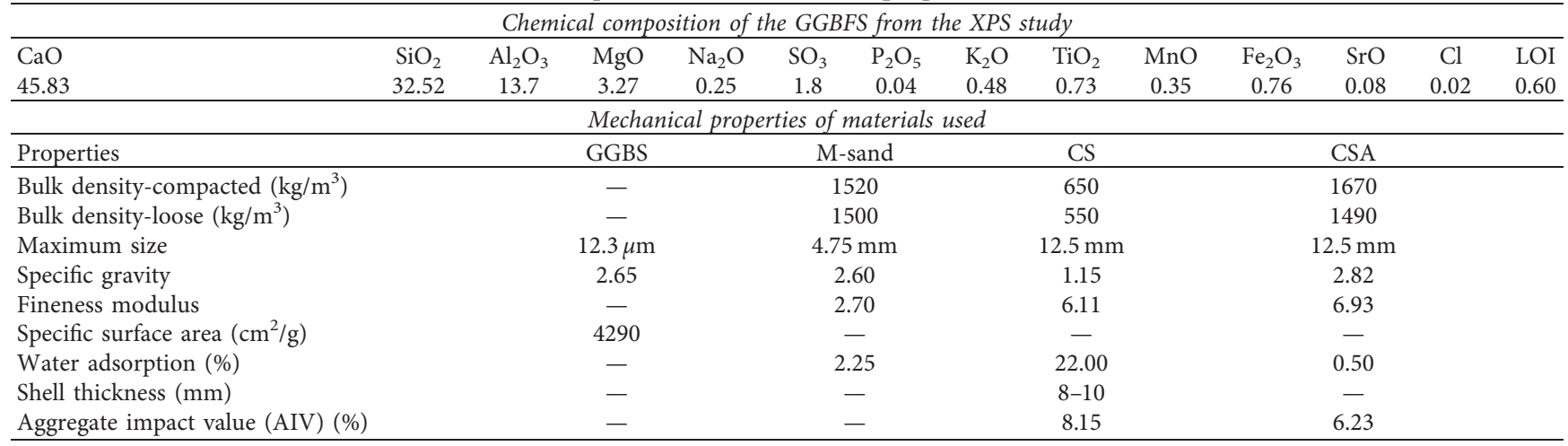

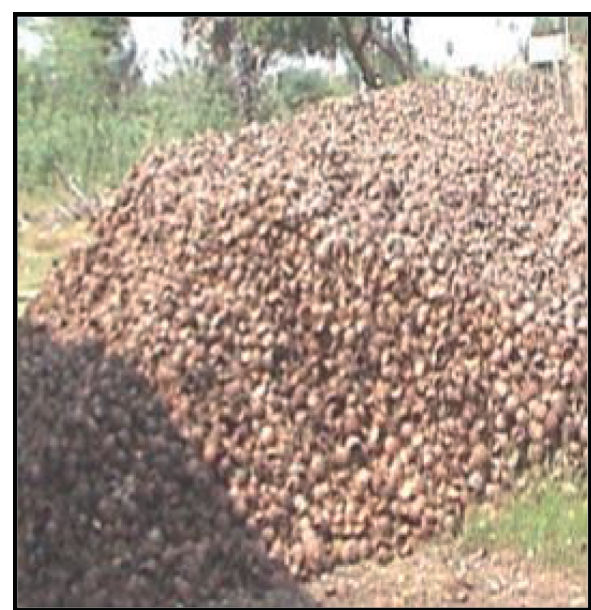

Discarded CS at CS yard

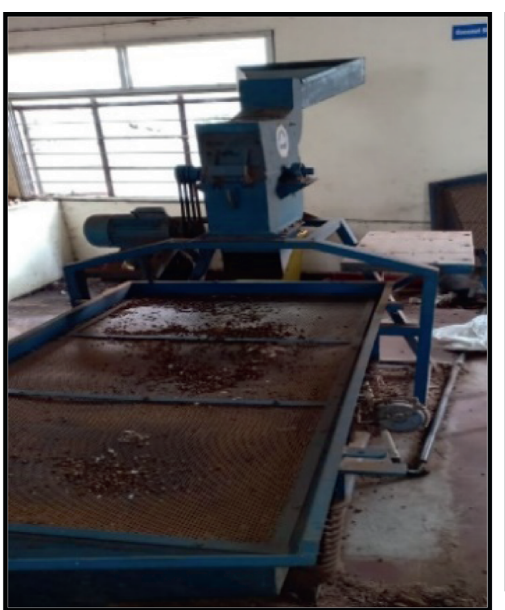

Crushing equipment

(a)
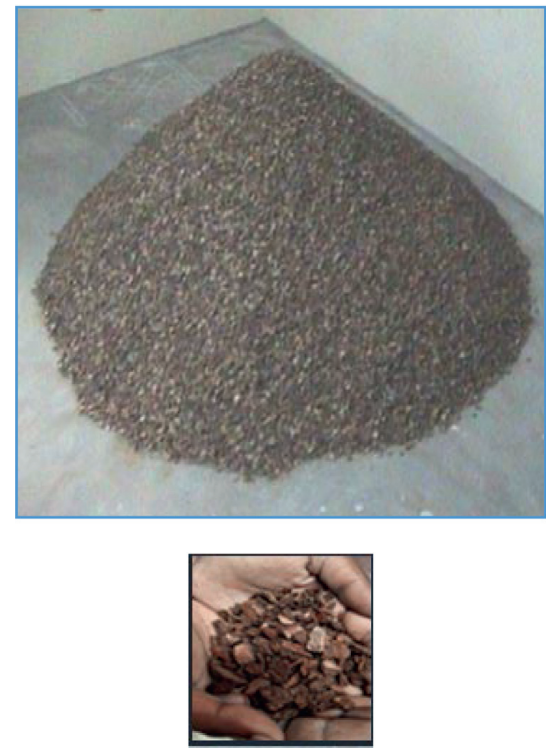

(b)

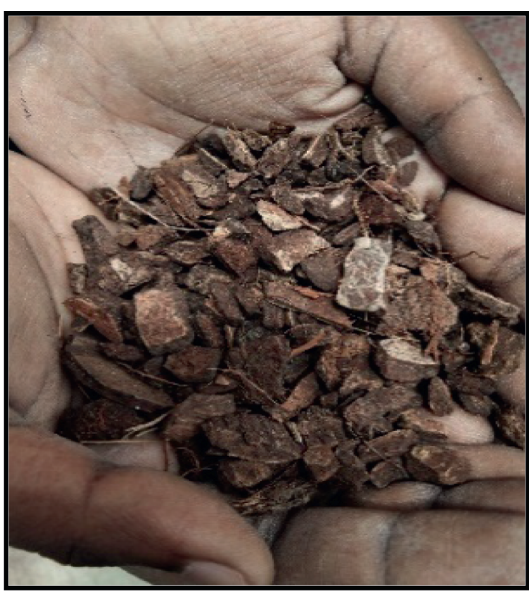

Crushed CS

FIgure 1: Continued. 

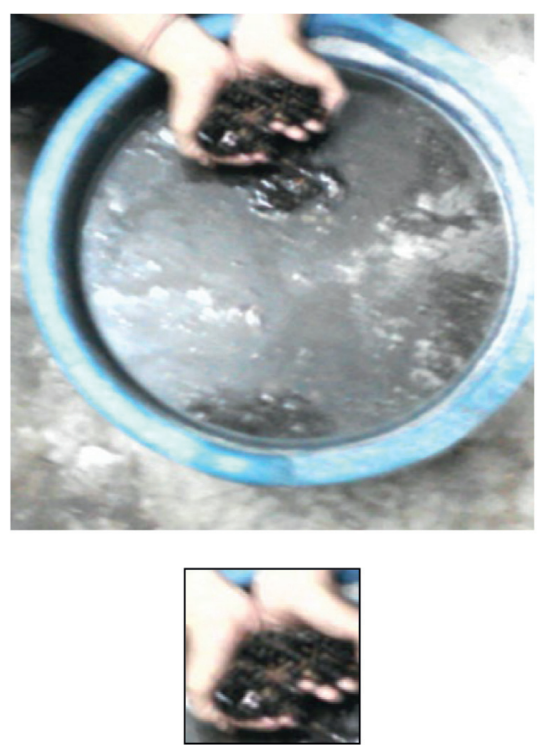

(c)
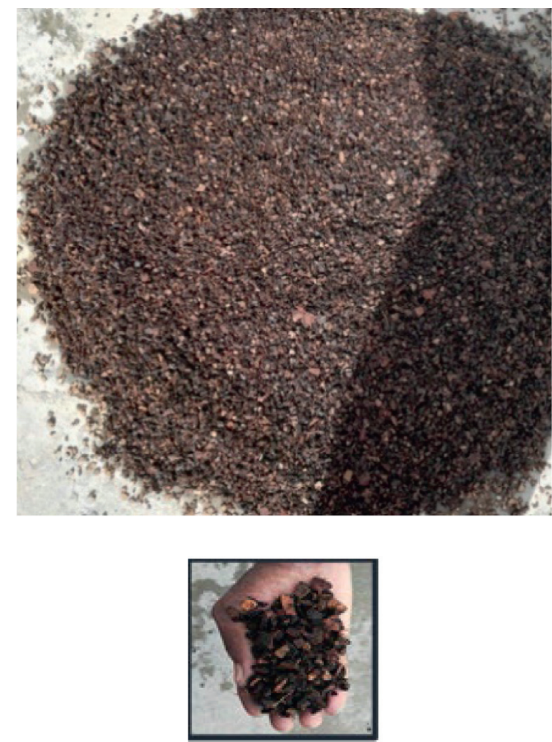

(d)

Figure 1: Processing of CS (SSD condition). (a) Preparation of raw coconut shell aggregate. (b) Raw crushed CS $12.5 \mathrm{~mm}$. (c) CS after immersion in water for $24 \mathrm{~h}$. (d) CS in SSD condition.

not be applied to the mix design for the concrete with agrowaste materials due to its structural behaviour. Thus, all the trial mixes were prepared based on the volume proportions and then converted into the weight proportion. To prepare the control mix, the volume of the coconut shell coarse aggregate was compared to that of the crushed granite gravel and kept constant. The mix proportions (GGBS: M-sand: CS/CSA) for GPCSC and GPCC and the amount of the alkaline activator solution with water content are shown in Table 2.
2.4. Details of the Beam Specimen. The flexural behaviour of reinforced GPCSC and GPCC was studied in two different cases: one is singly reinforced (steel reinforcements provided in the tension zone of the beams only) (Figure 2) and the second one is doubly reinforced beams (steel reinforcements provided in both tension and compression zone of the beams) as shown in Figure 3. The section was determined as under-reinforced/over-reinforced by using the limit state design method as per IS 456: 2000 [20]. Totally twelve beams were tested, of which six beams were GPCSC and six beams 
TABLE 2: Mix proportion of GPCSC and GPCC.

\begin{tabular}{|c|c|c|c|c|c|c|c|}
\hline \multirow{2}{*}{ Mix types } & \multirow{2}{*}{ Mix proportions } & \multirow{2}{*}{$\begin{array}{c}\text { Binder } \\
\text { GGBS }\left(\mathrm{kg} / \mathrm{m}^{3}\right)\end{array}$} & \multirow{2}{*}{$\begin{array}{l}\text { Fine aggregate } \\
\text { M-sand }\left(\mathrm{kg} / \mathrm{m}^{3}\right)\end{array}$} & \multicolumn{2}{|c|}{ Coarse aggregate } & \multicolumn{2}{|c|}{ Alkaline activator } \\
\hline & & & & $\mathrm{CS}\left(\mathrm{kg} / \mathrm{m}^{3}\right)$ & $\operatorname{CSA}\left(\mathrm{kg} / \mathrm{m}^{3}\right)$ & $\mathrm{NaOH}$ solution $\left(\mathrm{ml} / \mathrm{m}^{3}\right)$ & $\mathrm{Na}_{2} \mathrm{SiO}_{3}\left(\mathrm{ml} / \mathrm{m}^{3}\right)$ \\
\hline GPCSC & $1: 2.53: 1.05$ & 420 & 1064 & 443 & - & 46 & 228 \\
\hline GPCC & $1: 4.15: 3.56$ & 282 & 1172 & - & 1004 & 31 & 152 \\
\hline
\end{tabular}

ml: millilitre.

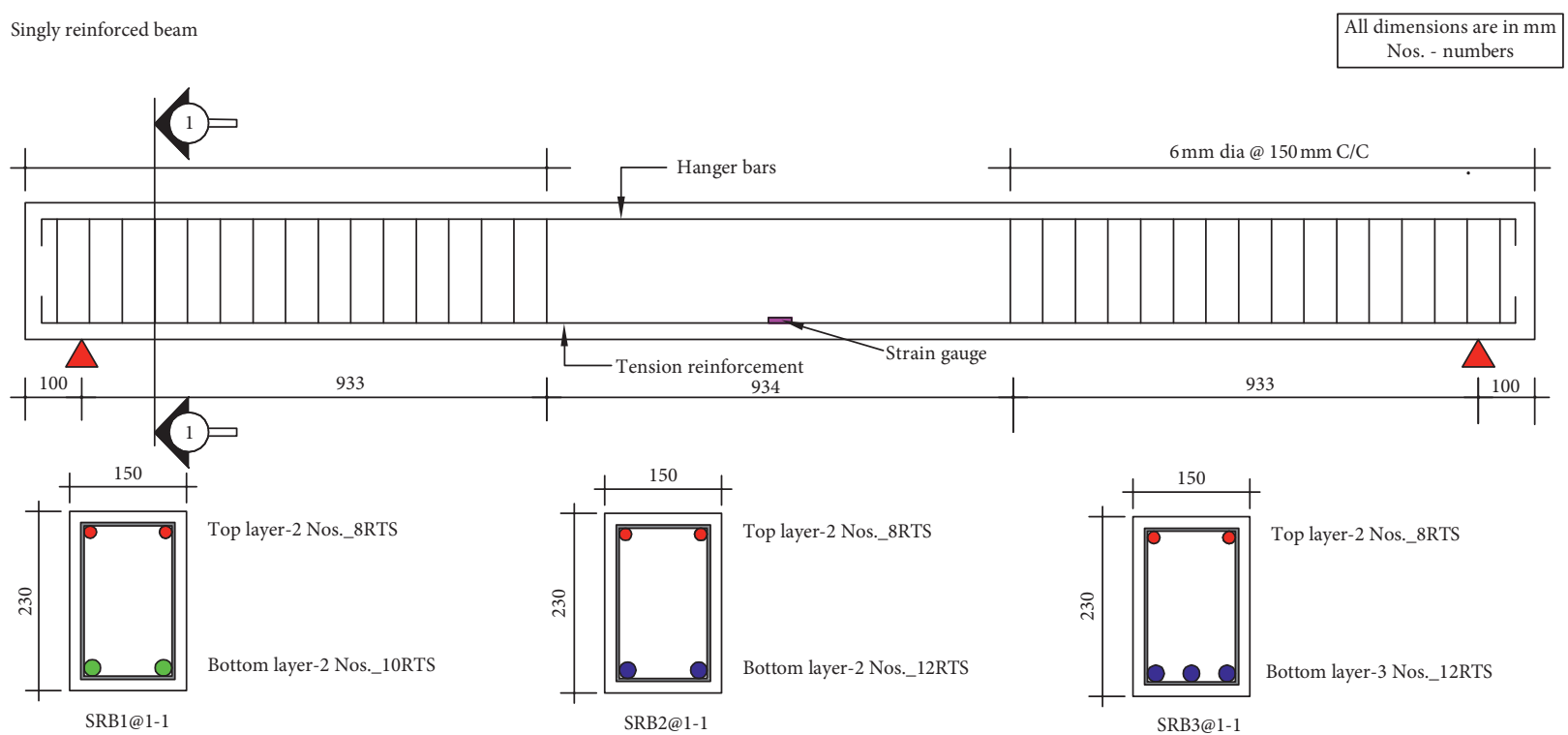

FIgURE 2: Reinforcement details and strain gauge location for SRB (S1, S2, and S3).

were GPCC. In addition to the beam specimen, the required number of cubes, cylinders, and prisms was cast and tested for its material characterizations. Cube specimen $100 \times 100 \times 100 \mathrm{~mm}$ in size was used and tested as per IS 516: 1959 [21] for compressive strength of concrete at the rate of $1.4 \mathrm{kN} / \mathrm{cm}^{2} / \mathrm{min}$. In the design of concrete structural elements, concrete tensile strength also plays a vital role. However, it is somewhat complex in nature to determine the tensile strength of concrete under uniaxial tension test, and hence splitting tensile strength tests are generally conducted on cylindrical specimens though it is an indirect method. Therefore, splitting tensile strength was carried out to determine the indirect tensile strength of concrete study in this research. As per ASTM C496-90 [22], a $100 \mathrm{~mm}$ diameter and $200 \mathrm{~mm}$ long cylindrical specimen was used for the splitting tensile strength test which gives tensile strength of concrete indirectly. The rate of loading given for this test is $0.7 \mathrm{kN} / \mathrm{min}$. The splitting tensile strength $f_{\text {st }}$ of specimens was calculated using the following equation:

$$
f_{\text {st }}=\frac{2 P}{\pi D L}(\mathrm{MPa})
$$

where $P$ is the maximum applied load in Newton, $D$ is the diameter of the cylinder in $\mathrm{mm}$, and $L$ is the length of the cylinder in $\mathrm{mm}$.

A two-point load method was adopted to measure the flexural strength of the specimen as per ASTM C78-84 [23]. Prisms $100 \times 100 \times 500 \mathrm{~mm}$ in size were used to find the flexural strength and tested as per IS 516:1959 [21] at the rate of $180 \mathrm{~kg} / \mathrm{min}$. The flexural strength $f_{t}$ of concrete specimens was calculated using the following equation:

$$
f_{t}=\frac{P L}{B D^{2}}(\mathrm{MPa}) \text {, }
$$

where $P$ is the maximum applied load in Newton, $L$ is the supported length of the prism in $\mathrm{mm}, B$ is the breadth of the prism in $\mathrm{mm}$, and $D$ is the depth of the prism in $\mathrm{mm}$.

As per ASTM C469-02 [24], cylindrical specimens $150 \mathrm{~mm}$ in diameter and $300 \mathrm{~mm}$ in height were used for the determination of elastic modulus. This method involves applying compressive load longitudinally to the specimen to calculate the elastic modulus. For this purpose, deformation was measured using an extensometer attached to the cylindrical specimen for every increments of the load. For every increment of applied load, stresses and strains were calculated and the stress-strain graph was drawn. From the stress-strain graph, the mean modulus of elasticity was calculated $[7,11]$ using the following equation:

$$
E=\frac{(S 2-S 1)}{(€ 2-0.000050)}(\mathrm{MPa})
$$

where $E$ is chord modulus of elasticity in $\mathrm{MPa}, S 2$ is stress corresponding to $40 \%$ of the ultimate load in $\mathrm{MPa}, S 1$ is stress corresponding to a longitudinal strain of $50 \times 10^{-6}$ in $\mathrm{MPa}$, and $€_{2}$ is longitudinal strain produced by $S 2$. 

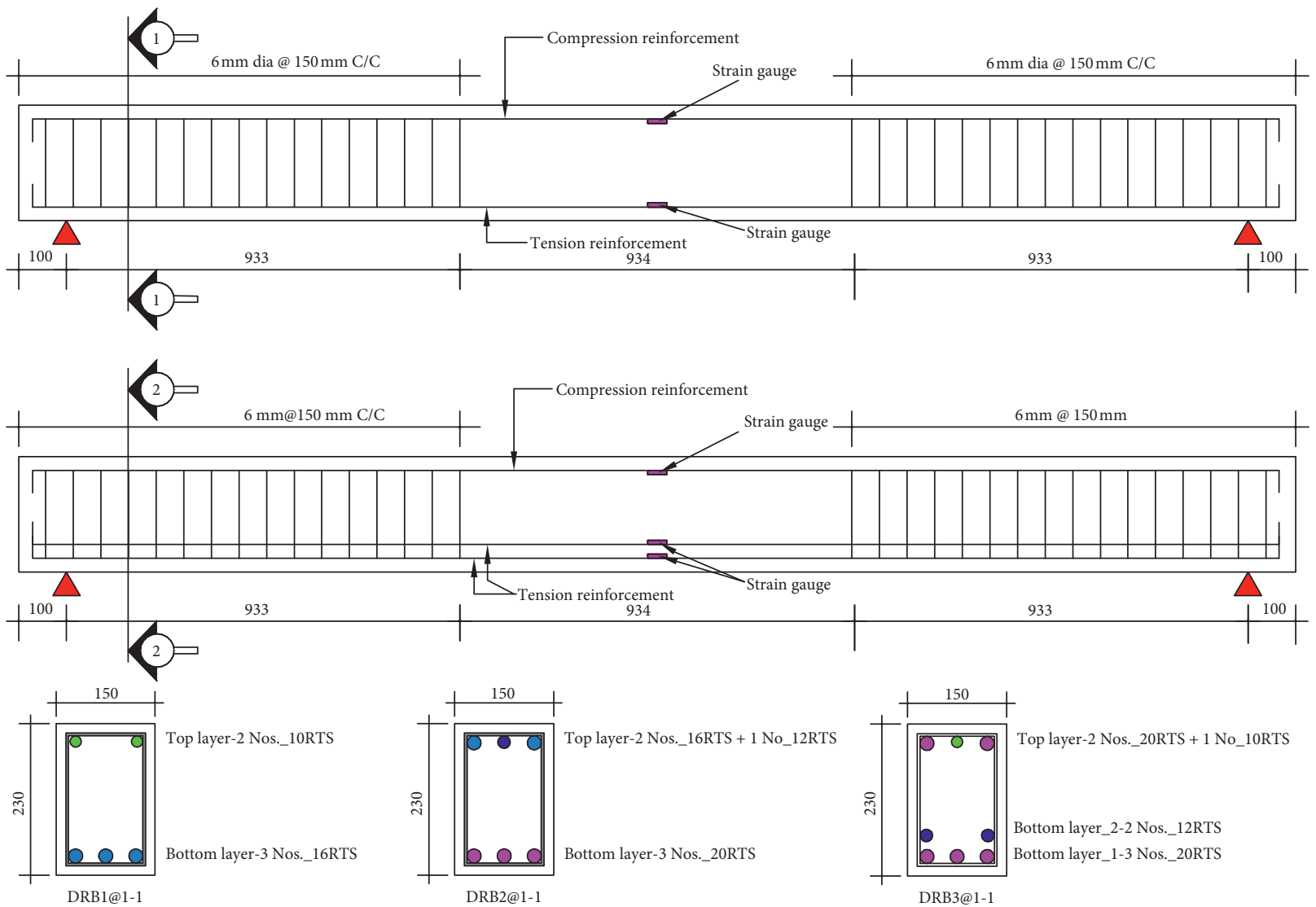

FIGURE 3: Reinforcement details and strain gauge location for DRB (D1, D2, and D3).

The determined properties of the concrete tested are given in Table 3. A schematic diagram of beam testing is shown in Figure 4. Singly reinforced beam (SRB) was represented as S1, S2, and S3 (Figure 3) and doubly reinforced beam (DRB) was represented as D1, D2, and D3 (Figure 4). The beam details with their corresponding ID and the percentage of used reinforcement and also total tension and compression area of reinforcements are given in Table 4.

All 12 specimens were cast with the overall dimension of length $(3000 \mathrm{~mm}), 150 \mathrm{~mm}$ (width), and overall depth $(230 \mathrm{~mm})$. The span to effective depth ratio was chosen as 15 to ensure the failure of the beam with flexural nature as per IS 456:2000 [20]. No shear reinforcement was provided in the pure bending region for a length of $934 \mathrm{~mm}$ as shown in Figures 3 and 4 . Also, sufficient shear links were provided at a spacing of $150 \mathrm{~mm}$ in the remaining distance. Fe500 grade of steel reinforcements (having Young's modulus $2.1 \times 105 \mathrm{~N} / \mathrm{mm}^{2}$ and yield strength $518 \mathrm{~N} / \mathrm{mm}^{2}$ ) confirming with the IS 1786: 2008 [25] was used in all the beams both in main reinforcement and in stirrups as well.

Strain gauges of length $10 \mathrm{~mm}$ were fixed at midspan in all the bars on both the compression zone and the tension zone to measure the strain in the provided reinforcement bar. The gauges on the surface of the bars were ground smooth with sandpaper of approximate length $20 \mathrm{~mm}$ to facilitate the fixing of the $10 \mathrm{~mm}$ strain gauge, with a gauge resistance of $120 \mathrm{ohms}$, and the wire that was extended was covered with a fiberglass sleeve material. The strain gauges were fixed with gloves applied in the reinforcing bar and the surface of the strain gauges covered with waterproofing tape to prevent water entry and damage during casting. The functioning of the fixed strain gauge in reinforcement must be cross-checked by measuring the output resistance of $120 \mathrm{ohms}$ using a multimeter to avoid damage while fixing and protecting. Figure 5 presents the procedure to fix the strain gauge in the reinforcement and the technique to check its functioning of strain gauge resistance using a multimeter.

2.5. Casting and Curing of the Beam Specimens. For casting all the specimens, the ingredients were weighed and mixed in a concrete mixture as per the trail mix proportions mentioned in Table 2. Wooden mould was used for casting the beam specimens. The bottom and sides of the moulds were bolted properly to avoid air gap and also for easy demoulding. The designed reinforcement is placed inside the mould leaving sufficient cover at the sides and at the bottom using cover blocks (cement masonry cover block). The ingredients were dry-mixed for 3-4 min and alkaline activators 
TABle 3: Properties of geopolymer concrete.

\begin{tabular}{|c|c|c|c|c|c|c|}
\hline \multirow{2}{*}{ Mechanical properties } & \multicolumn{3}{|c|}{ GPCSC } & \multicolumn{3}{|c|}{ GPCC } \\
\hline & Results & No. of samples & Standard deviation & Results & No. of samples & Standard deviation \\
\hline 28-day density $\left(\mathrm{kg} / \mathrm{m}^{3}\right)$ & 1980 & & 2.52 & 2440 & & 9.07 \\
\hline Compressive strength (MPa) & 32.6 & & 0.32 & 35.2 & & 0.21 \\
\hline Flexural strength $(\mathrm{MPa})$ & 4.1 & 3 & 0.21 & 3.6 & 3 & 0.21 \\
\hline Split tensile strength $(\mathrm{MPa})$ & 3.0 & & 0.15 & 3.1 & & 0.15 \\
\hline Modulus of elasticity (GPa) & 7.3 & & 0.10 & 12.9 & & 0.35 \\
\hline
\end{tabular}

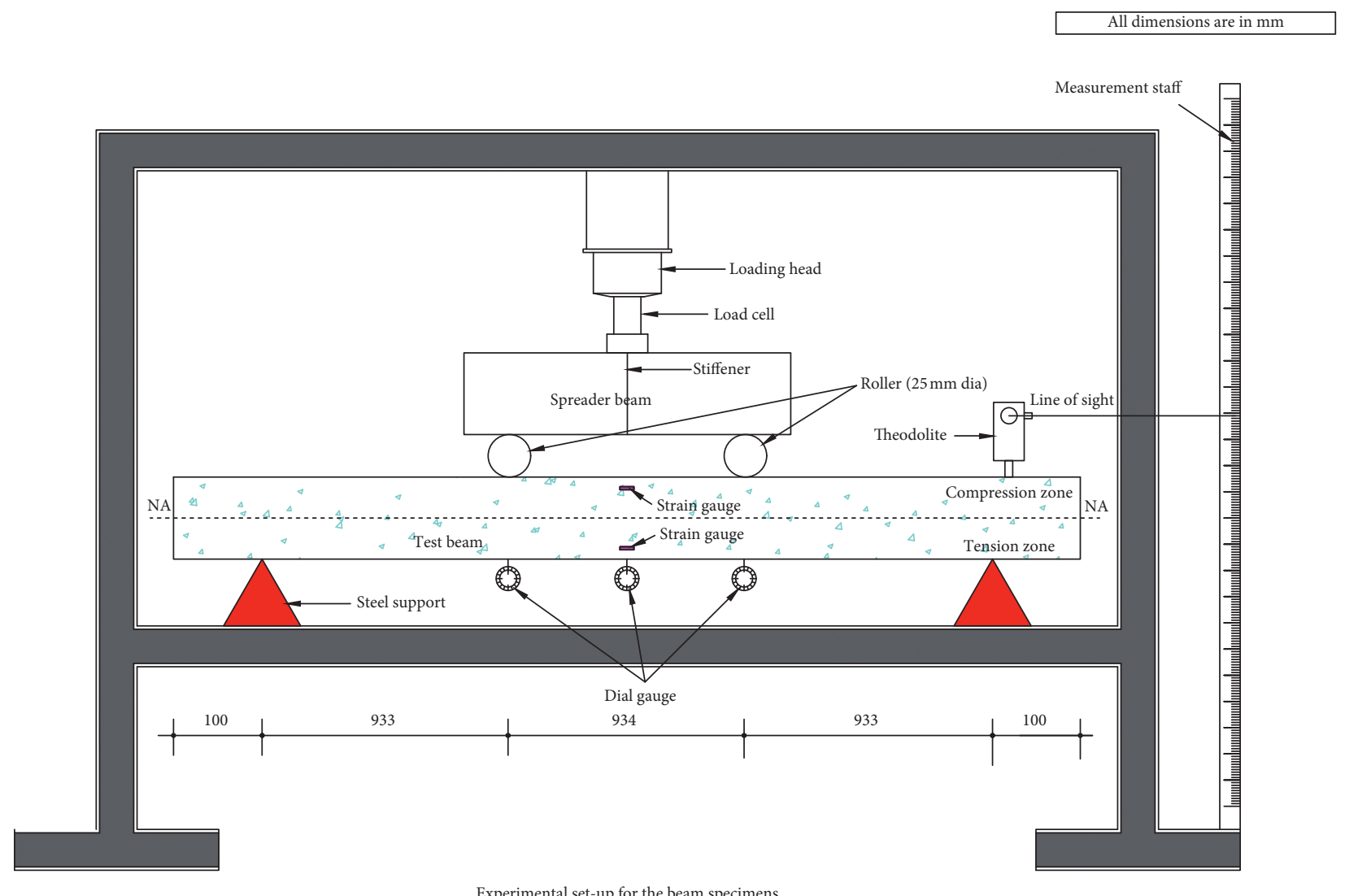

FIgURE 4: Schematic diagram of beam testing.

of designed proportion were mixed gradually and the wet mix was allowed in the mixture machine for $5 \mathrm{~min}$. The wet mix was placed in the mould in three layers and compaction was done using a needle vibrator. Proper care was taken for uniform compaction and surface finish throughout the beam. Immediately after casting, the specimens were covered with a polyethene sheet and they were demoulded after $24 \mathrm{~h}$ for concealed curing as per ASTM C171-16 [26] to prevent evaporation of water.

2.6. Specimen Preparation and Instrumentations. After 28 days of concealed curing, the beams were painted with white powder to observe cracks at the time of the test. A day before the specimens attained their age of 28 days, the beams were carefully removed from the polythene cover and painted with whitewash powder. The beam was placed on the loading frame and supported at $100 \mathrm{~mm}$ from each beam end that produced a beam clear span of $2800 \mathrm{~mm}$ (centre to centre distance from the support). Two symmetrical point loads were acting at one-third of the beam clear span as shown in Figure 6. The source of the load was applied through a hydraulic jack connected with a load cell of $1000 \mathrm{kN}$ maximum capacity with the tolerance limit $\pm 2 \%$. A dial gauge with a least count of $0.001 \mathrm{~mm}$ was used to measure the deflection of the beam under the loads. Crack widths were measured with a crack microscope that reads to an accuracy of $0.02 \mathrm{~mm}$ on the surface of the beams. The proving ring was set to zero before the readings were taken. Prior to the load application on the setup, all the equipment was properly monitored to ensure that they were in their correct position. The beam specimens were then loaded gradually, with an incremental stage. At the time of the test, the loads were applied incrementally at a rate of $1 \mathrm{kN}$ until failure. The tensile and compressive strains of both reinforcements and concrete were measured through electrical resistance gauges. 
TABLe 4: Beam details (width, $150 \mathrm{~mm}$; effective depth, $200 \mathrm{~mm}$; and overall length, $3000 \mathrm{~mm}$ ).

\begin{tabular}{|c|c|c|c|c|c|c|}
\hline Beam ID & $\begin{array}{c}\text { Nominal } \\
\text { reinforcement }\end{array}$ & $\begin{array}{c}\text { Compression } \\
\text { reinforcement }\end{array}$ & $\begin{array}{l}\text { Tension } \\
\text { reinforcement }\end{array}$ & $\begin{array}{c}\text { Shear } \\
\text { reinforcement }\end{array}$ & $\begin{array}{c}\text { Area of tensile } \\
\text { reinforcement } A_{\text {st }}\left(\mathrm{mm}^{2}\right)\end{array}$ & $\begin{array}{c}P=\underset{\text { st }}{A_{\text {st }} / b d} \\
(\%)\end{array}$ \\
\hline $\begin{array}{l}\text { GPCSC } \\
-S 1\end{array}$ & 2 nos. of $8 \mathrm{~mm} \phi$ & - & 2 nos. of $10 \mathrm{~mm} \phi$ & $\begin{array}{c}6 \mathrm{~mm} \phi @ 150 \mathrm{~mm} \\
\mathrm{c} / \mathrm{c}\end{array}$ & 157.079 & 0.52 \\
\hline $\begin{array}{l}\text { GPCSC } \\
-S 2\end{array}$ & 2 nos. of $8 \mathrm{~mm} \phi$ & - & 2 nos. of $12 \mathrm{~mm} \phi$ & $\begin{array}{c}6 \mathrm{~mm} \phi \mathrm{c}_{\mathrm{c} / \mathrm{c}} 150 \mathrm{~mm} \\
\end{array}$ & 226.195 & 0.75 \\
\hline $\begin{array}{l}\text { GPCSC } \\
-S 3\end{array}$ & 2 nos. of $8 \mathrm{~mm} \phi$ & - & 3 nos. of $12 \mathrm{~mm} \phi$ & $\begin{array}{c}6 \mathrm{~mm} \phi @ 150 \mathrm{~mm} \\
\mathrm{c} / \mathrm{c}\end{array}$ & 339.292 & 1.13 \\
\hline GPCC -S1 & 2 nos. of $8 \mathrm{~mm} \phi$ & - & 2 nos. of $10 \mathrm{~mm} \phi$ & $\begin{array}{c}6 \mathrm{~mm} \phi @ 150 \mathrm{~mm} \\
\mathrm{c} / \mathrm{c}\end{array}$ & 157.079 & 0.52 \\
\hline GPCC- S2 & 2 nos. of $8 \mathrm{~mm} \phi$ & - & 2 nos. of $12 \mathrm{~mm} \phi$ & $\begin{array}{c}6 \mathrm{~mm} \phi @ 150 \mathrm{~mm} \\
\mathrm{c} / \mathrm{c}\end{array}$ & 226.195 & 0.75 \\
\hline GPCC- S3 & 2 nos. of $8 \mathrm{~mm} \phi$ & - & 3 nos. of $12 \mathrm{~mm} \phi$ & $\begin{array}{c}6 \mathrm{~mm} \phi @ 150 \mathrm{~mm} \\
\mathrm{c} / \mathrm{c}\end{array}$ & 339.292 & 1.13 \\
\hline $\begin{array}{l}\text { GPCSC- } \\
\text { D1 }\end{array}$ & - & 2 nos. of $10 \mathrm{~mm} \phi$ & 3 nos. of $16 \mathrm{~mm} \phi$ & $\begin{array}{c}6 \mathrm{~mm} \phi @ \\
150 \mathrm{~mm} \mathrm{c} / \mathrm{c}\end{array}$ & 603.185 & 2.01 \\
\hline $\begin{array}{l}\text { GPCSC- } \\
\text { D2 }\end{array}$ & - & $\begin{array}{c}2 \text { nos. of } 16 \mathrm{~mm} \phi \& \\
1 \text { no of } 12 \mathrm{~mm} \phi\end{array}$ & 3 nos. of $20 \mathrm{~mm} \phi$ & $\begin{array}{l}6 \mathrm{~mm} \phi @ \\
150 \mathrm{~mm} \mathrm{c} / \mathrm{c}\end{array}$ & 942.478 & 3.14 \\
\hline $\begin{array}{l}\text { GPCSC } \\
\text {-D3 }\end{array}$ & - & $\begin{array}{c}2 \text { nos. of } 20 \mathrm{~mm} \phi \& \\
1 \text { nos. of } 10 \mathrm{~mm} \phi\end{array}$ & $\begin{array}{c}3 \text { nos. of } 20 \mathrm{~mm} \phi \\
\& \\
2 \text { nos. of } 12 \mathrm{~mm} \phi\end{array}$ & $\begin{array}{l}6 \mathrm{~mm} \phi @ \\
150 \mathrm{~mm} \mathrm{c} / \mathrm{c}\end{array}$ & 1168.672 & 3.90 \\
\hline GPCC -D1 & - & 2 nos. of $10 \mathrm{~mm} \phi$ & 3 nos. of $16 \mathrm{~mm} \phi$ & $\begin{array}{c}6 \mathrm{~mm} \phi @ \\
150 \mathrm{~mm} \mathrm{c} / \mathrm{c}\end{array}$ & 603.185 & 2.01 \\
\hline GPCC -D2 & - & $\begin{array}{l}2 \text { nos. of } 16 \mathrm{~mm} \phi \& \\
1 \text { no of } 12 \mathrm{~mm} \phi\end{array}$ & 3 nos. of $20 \mathrm{~mm} \phi$ & $\begin{array}{c}6 \mathrm{~mm} \phi @ \\
150 \mathrm{~mm} \mathrm{c} / \mathrm{c}\end{array}$ & 942.478 & 3.14 \\
\hline GPCC -D3 & - & $\begin{array}{c}2 \text { nos. of } 20 \mathrm{~mm} \phi \& \\
1 \text { no of } 10 \mathrm{~mm} \phi\end{array}$ & $\begin{array}{c}3 \text { nos. of } 20 \mathrm{~mm} \phi \\
\& \\
2 \text { nos. of } 12 \mathrm{~mm} \phi\end{array}$ & $\begin{array}{c}6 \mathrm{~mm} \phi @ \\
150 \mathrm{~mm} \mathrm{c} / \mathrm{c}\end{array}$ & 1168.672 & 3.90 \\
\hline
\end{tabular}

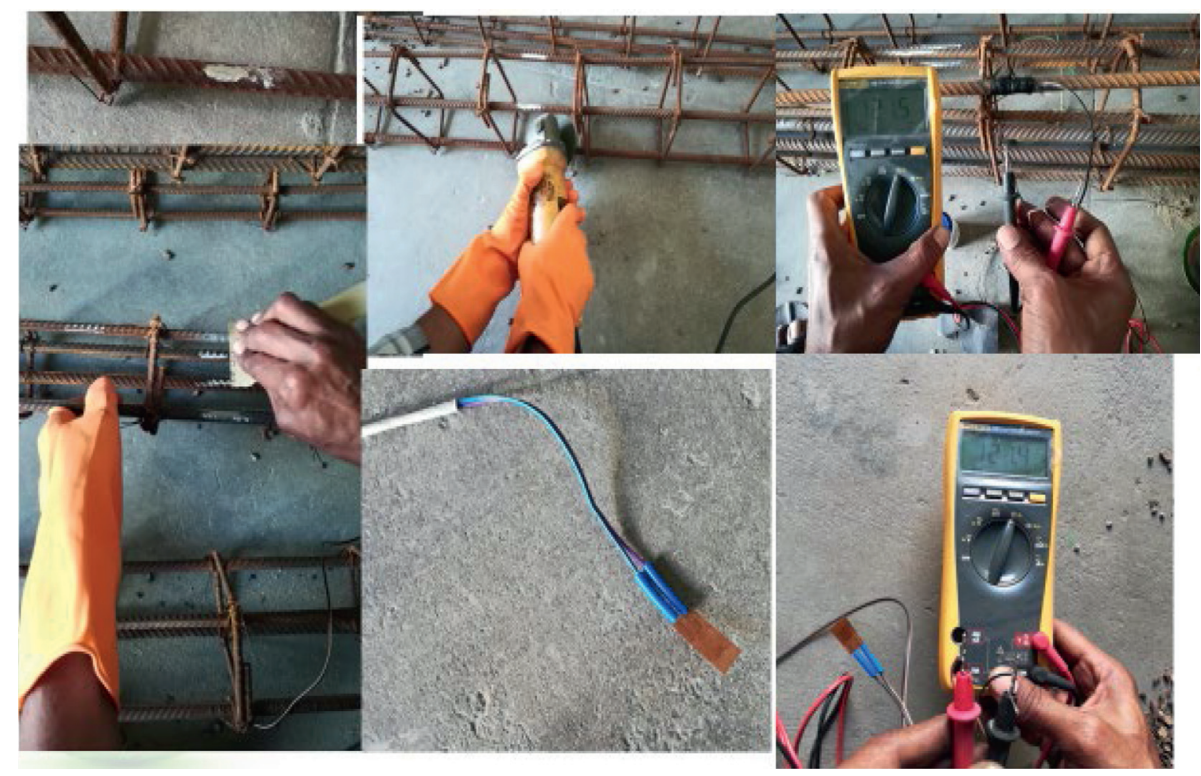

Figure 5: Procedure to fix strain gauge. 


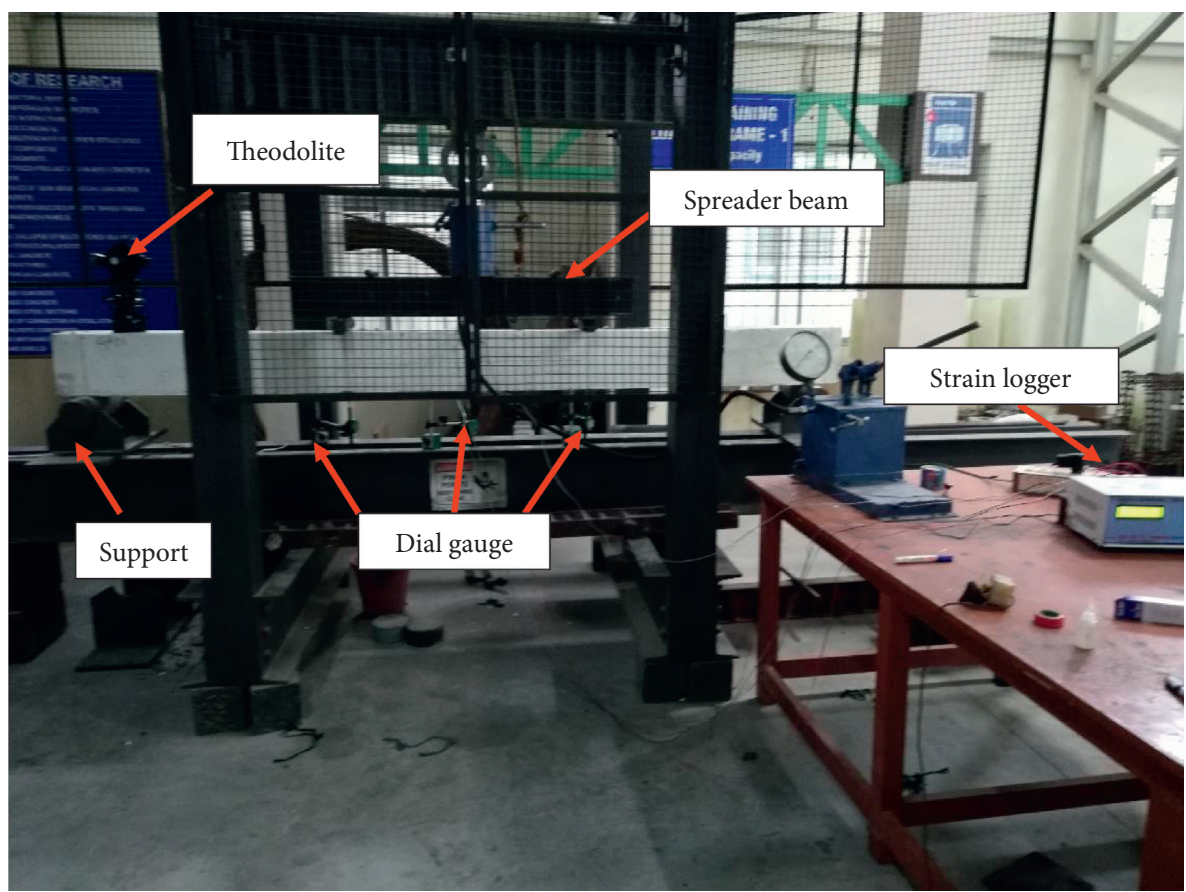

Figure 6: Test setup in the loading frame for the beam.

All the strains were recorded using a 32 channel CALPlex data logger. A theodolite and a levelling staff were used to measure the end rotation on the incremental.

\section{Results and Discussion}

3.1. General Observations of the Tested Beams. All beams (GPCSC and GPCC) showed typical behaviour in flexure. Since the concave and convex surfaces of the coconut shell aggregate are smooth, bond failure may occur during testing in GPCSC concrete [10]. However, no horizontal cracks were observed at the level of the reinforcement, which indicated that there were no occurrences of bond failure. Vertical flexural cracks were observed in the constant moment region and sufficient warning was observed with a significant amount of ultimate deflection. The end rotation of the GPCSC beam was higher when compared to the GPCC beam. Similar findings were reported in oil palm shell concrete $[27,28]$.

3.2. Crack Pattern and Failure Mode. For all the tested beams, a few fine vertical flexural cracks first developed within the pure bending-moment zone, when the bendingmoment exceeded the cracking moment of the beams. Once the cracks are formed at mid-span, their propagation is more parallel to each other and normal to the axis of the beam. The crack patterns at the failure of GPCSC and GPCC beams are shown in Figures 7-10. The crack patterns and modes of failure were dissimilar due to the value of reinforcement ratio and the diameter of reinforcement used in the tension and compression zone tests, for both GPCSC and GPCC. In general, this crack spacing mechanism is described as a function of a bond between the reinforcement and the concrete $[10,27,28]$.

Figures 7 and 8 depict the crack pattern up to peak load for all the tested singly reinforced beams (GPCSC and GPCC). The number of cracks developed along the span of GPCC was smaller than that of GPCSC, especially in the pure bending zone. The possible reason may be that of higher compressive strength and modulus of elasticity of GPCC compared to GPCSC as summarized in Table 3. But the cracks were wider and mostly concentrated at mid-span in the pure bending zone, at the time of yielding steel reinforcements in this region for both GPCSC and GPCC. Once the cracks are formed in the pure bending zone, the formed cracks progressed both lengthwise and widthwise since in that pure bending zone shear reinforcements are not provided intentionally to study the behaviour of beam under flexure. Also, it was found that the vertical cracks formed initially in both the end of the shear spans are further inclined at higher loads. This was observed in both GPCC and GPCSC beams. Therefore, it can be stated that the behaviour of GPCSC is very similar to GPCC beams. At the final loading stage, very few inclined cracks reached the compression zone of the geopolymer concrete. Based on Figures 7 and 8, the cracks were almost uniformly distributed along the beam span with an average spacing of $98 \mathrm{~mm}$ for GPCSC and $156 \mathrm{~mm}$ for GPCC, respectively.

Figures 9 and 10 depict the crack pattern at peak load for all the tested doubly reinforced beams (GPCSC and GPCC). The number and width of cracks developed along the span for DRB were higher when compared to SRB for both GPCSC and GPCC. The vertical cracks in the shear span were inclined due to the shear stress similar to SRB. At the final loading stage, many inclined cracks reached the 


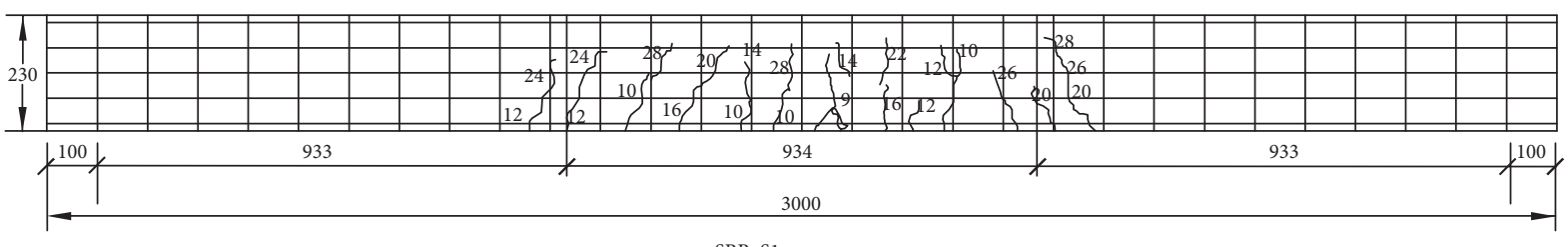

SRB_S1
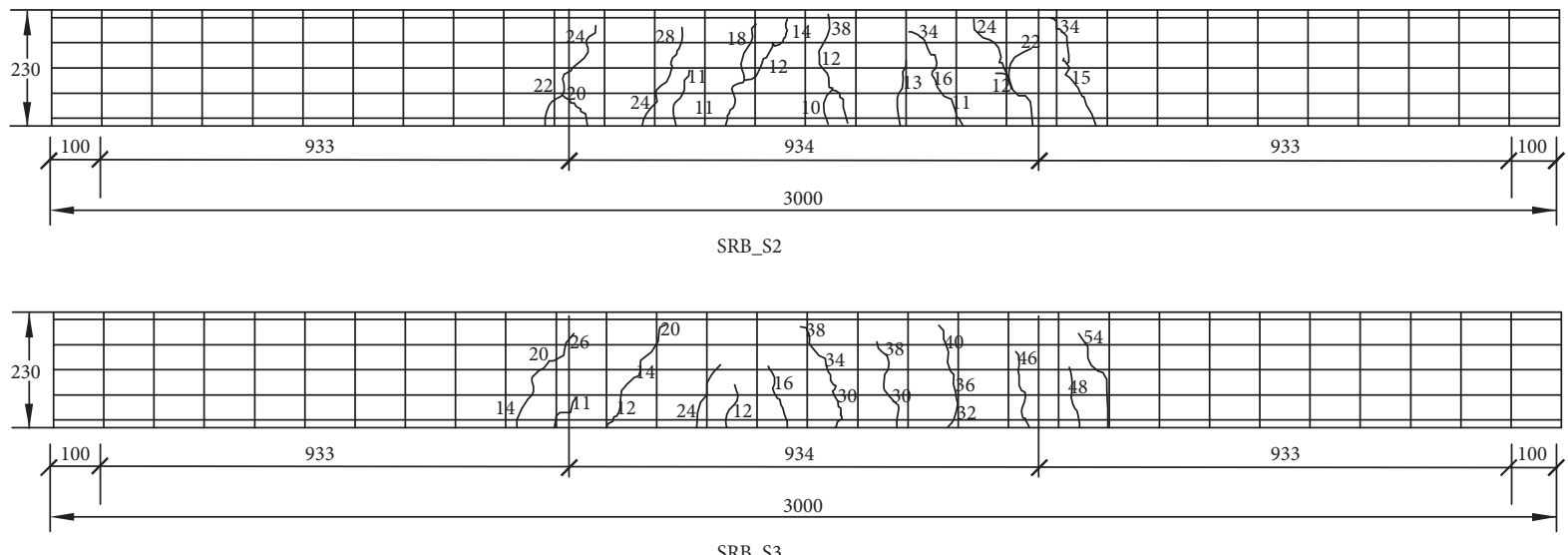

FIGURE 7: The crack pattern of GPCSC for singly reinforced beam (SRB).
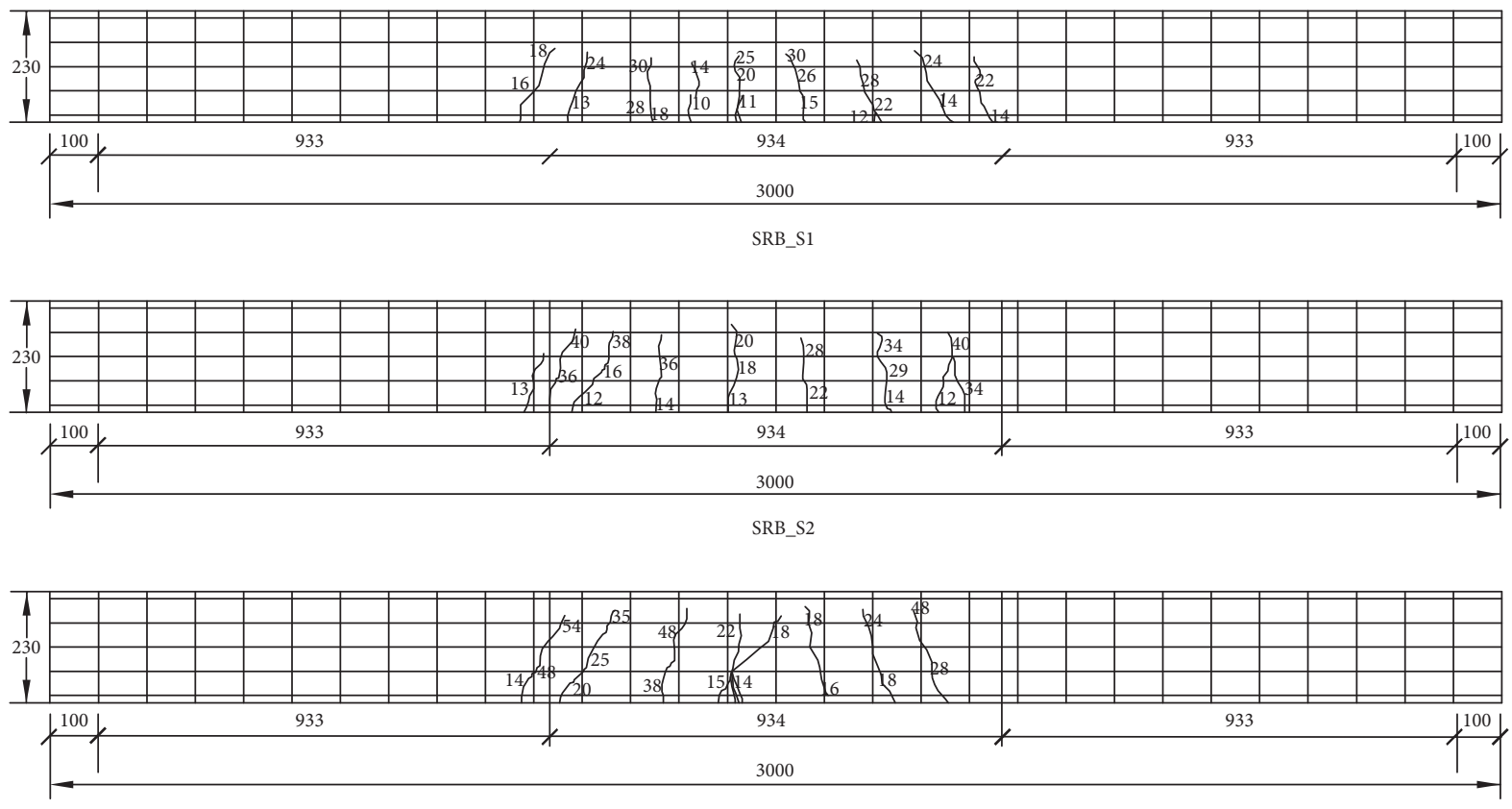

SRB_S3

FIGURE 8: Crack pattern of GPCC for singly reinforced beam (SRB). 


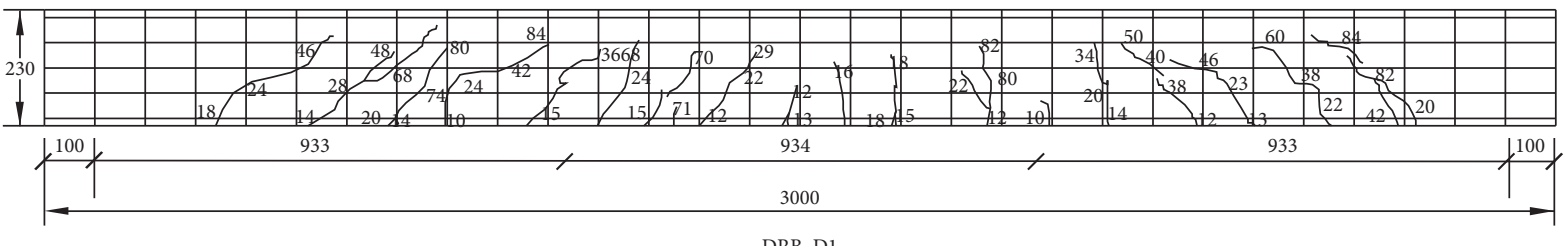

DRB_D1

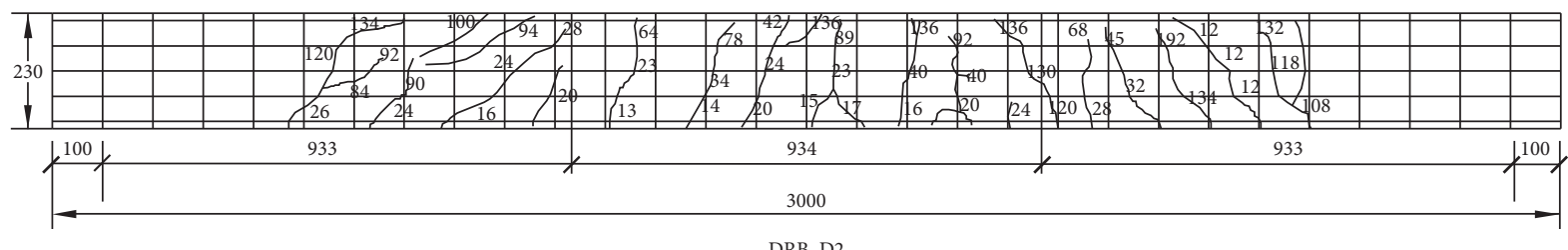

DRB_D2

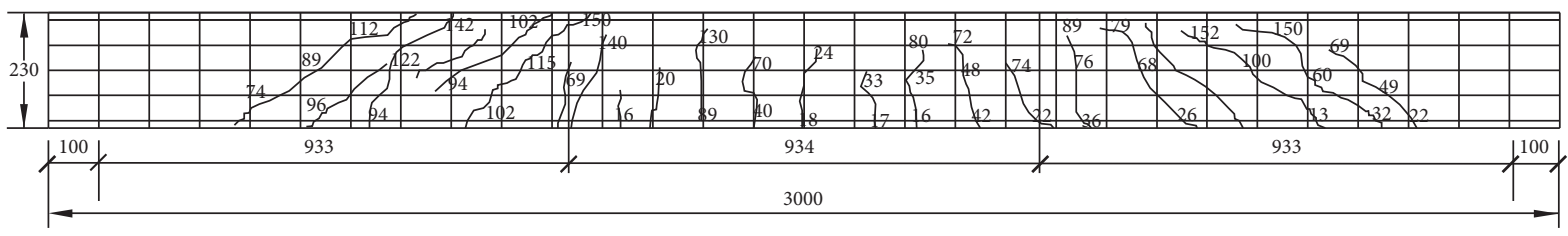

DRB_D3

FIGURE 9: Crack pattern of GPCSC for doubly reinforced beam (DRB).
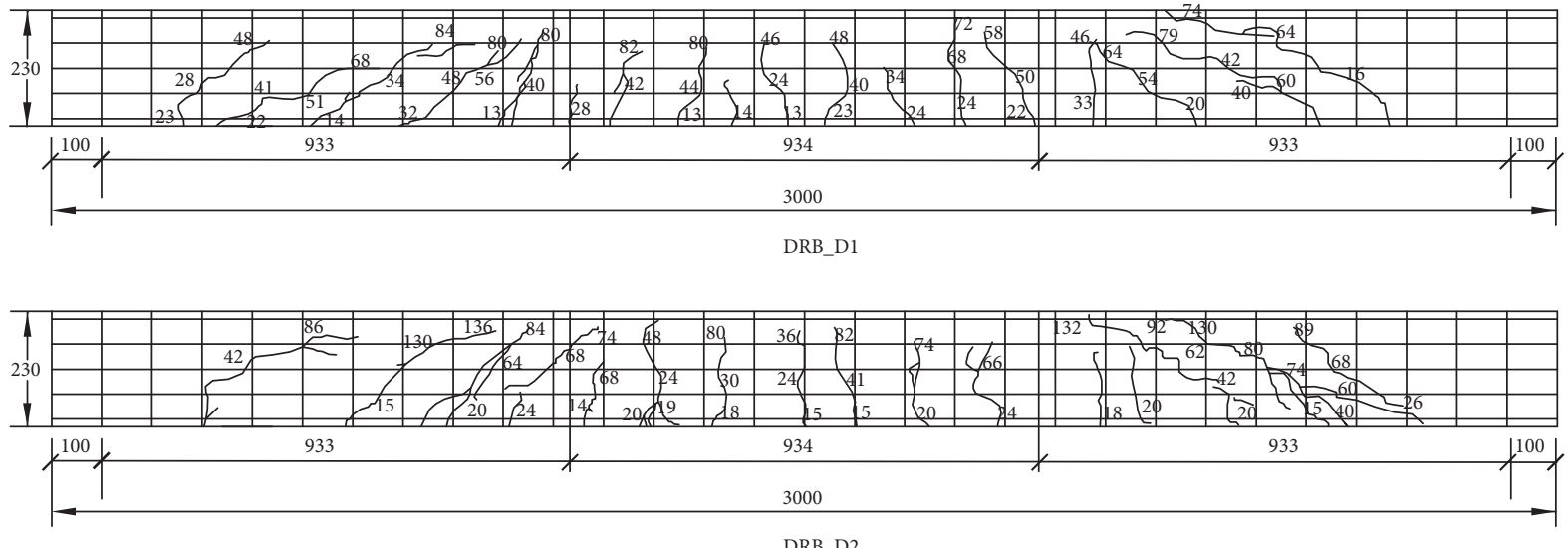

DRB_D2

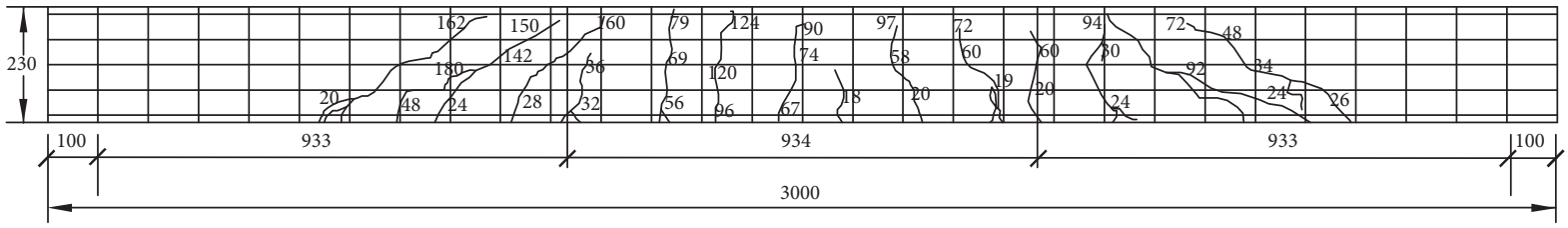

DRB_D3

FIGURE 10: The crack pattern of GPCC for doubly reinforced beam (DRB). 
compression zone of the geopolymer concrete in DRB when compared with SRB. Based on Figures 9 and 10, the cracks were almost uniformly distributed along the beam span with the spacing of approximately $75 \mathrm{~mm}$ for both GPCSC and GPCC.

Overall, this observation of crack patterns demonstrated that a composite action existed between the reinforcing bars and the geopolymer concrete. This study reveals that proper bonding exists between the reinforcements and both GPCC and GPCSC concretes and hence integration among them are also a perfect indication from the crack patterns observed. The number of cracks formed in the DRB was more compared to SRB for both GPCC and GPCSC beams. The reason for more cracks in the DRB is due to higher moment of resistance due to the higher reinforcement ratio compared to SRB. However, it was found that the maximum crack width of crack in the case of DRB $(3.02 \mathrm{~mm}, 2.45 \mathrm{~mm}$, and $1.98 \mathrm{~mm})$ is less compared to SRB $(3.59 \mathrm{~mm}, 3.14 \mathrm{~mm}$, and $2.98 \mathrm{~mm}$ ) and the reason behind this is the higher modulus of elasticity of the GPCC than the GPCSC as shown in Table 3. The total number of cracks that developed in GPCSC and GPCC is given in Table 5. It was observed that the width of the cracks was considerably reduced for DRB when compared with SRB for both GPCSC and GPCC. Similar findings were reported in oil palm shell concrete $[27,28]$.

3.3. Influence of the Reinforcement Ratio. The flexural stiffness of the beams of GPCSC and GPCC increases as the reinforcement ratio increases. Thus, it can be deduced from the experimental results that the serviceability (within permissible limits of deflection and crack width for the size of beam used) performance of a geopolymer concrete beam can be enhanced by increasing the amount of longitudinal reinforcement. This improvement can be clearly understood by assuming the bars as parallel springs. As the number of bars increased, the overall stiffness also increased, thereby lowering the deflection after cracking, and limiting the crack width (Table 5) $[29,30]$. The flexural stiffness increased with increasing longitudinal rigidity and suggested that the reinforcement ratio should be increased in order to effectively control crack widths [30]. The test results clearly show that the deflection of the geopolymer beams (both GPCSC, Figures 11 and 12, and GPCC, Figures 13 and 14) decreased for the same load level with an increase in the reinforcement ratio. The theoretical design moment of the beams was calculated using the stress block analysis as recommended by IS 456:2000.

It was found that the ultimate moment obtained from the experiments was approximately 5\%-15\% higher for singly reinforced beams when compared to the theoretical moments. It is mainly due to the lower reinforcement ratio $(0.52 \%-1.13 \%)$ (Table 6 , singly reinforced beam) and geopolymer concrete impact. But for beams with a high reinforcement ratio $(2.01 \%-3.89 \%)$ (Table 6 , doubly reinforced beam), the experimental ultimate moment was only $1 \%-7 \%$ higher for both doubly reinforced geopolymer beams. The capacity ratio is taken as the ratio of an experimental ultimate moment to the theoretical ultimate moment. The capacity ratio varies between 1.05 and 1.15 for SRB and 0.98-1.07 for DRB indicates the virtuous resisting capacity of the section of the beam tested. Moments calculated using the standard IS 456:2000 can be conservative and can be used to predict the moment capacity for both GPCC and GPCSC beams. Also, the results obtained in this study are compared with the findings of other researchers on lightweight concrete beams and presented in Table 7 . It can be observed that the current research is consistent with the findings of other similar research [29-33].

3.4. Mid-Span Deflection Behaviour. Generally, all beams exhibited a similar load-deflection pattern. Tables 8 and 9 show the results of deflection of beams at service stage, ultimate stage, and permissible deflection as per IS456:2000 [20] and also as per ASTM C 778 [23]. Typical experimental moment deflection curves for the singly reinforced GPCSC and GPCC beams are shown in Figures 11 and 12, respectively. The moment deflection curves for doubly reinforced beams of GPCSC and GPCC are shown in Figures 13 and 14 , respectively.

The slope of the moment-deflection curve was steep and mostly linear before cracking occurred in all geopolymer beams. Here, the stiffness of the member is initially provided by the total concrete and steel area. A change in slope of the moment-deflection curve was observed once flexural cracks formed due to the reduction in stiffness in both GPCSC and GPCC. The formation of flexural cracks in GPCSC was earlier due to the porous nature of the coconut shell and it also has low density and modulus of elasticity which directly influences the stiffness of the aggregate. At the latter stage, the moment-deflection curve indicated large increases in deflection with a small increase in load. It can be observed that GPCSC beams exhibit a behaviour similar to that of GPCC beams.

Although CSC has a low modulus of elasticity, the deflection under the design service loads for the singly reinforced beams was acceptable as the span-deflection ratios ranged from $96.59 \mathrm{~mm}$ to $235.89 \mathrm{~mm}$ and were larger than the allowable limit provided by IS456:2000 [20]. In doubly reinforced beams, the span-deflection ratio ranged from $52.37 \mathrm{~mm}$ to $111.02 \mathrm{~mm}$ and this was larger than the allowable limit provided by IS 456:2000 [20]. It must be noted that the current experiments only involve short-term deflection and do not allow for evaluating shrinkage and associated creep.

Also, it can be noted that there is no code and standards are available for LWC especially for CSC and in combination with geopolymer; IS 456:2000 reference is taken only for guidance in this deflection parameter since this IS 456:2000 is established for concrete produced with traditional materials. Therefore, though permissible deflection as per IS 456:2000 is exceeding for both GPCC and GPCSC, it could be studied further to control the deflection within 
TABLE 5: Crack width, reinforcement ratio, and number of cracks.

\begin{tabular}{|c|c|c|c|c|}
\hline Beam ID & Neutral axis depth $\left(x_{u}\right)(\mathrm{mm})$ & Reinforcement ratio $(\% P) P=\left(A_{\mathrm{st}} / b d\right)$ in $(\%)$ & Crack width $(\mathrm{mm})$ & Number of cracks \\
\hline \multicolumn{5}{|c|}{ Singly reinforced beam (SRB) } \\
\hline GPCSC-S1 & 48.60 & 0.52 & 3.59 & 25 \\
\hline GPCSC-S2 & 70.63 & 0.75 & 3.14 & 22 \\
\hline GPCSC-S3 & 103.11 & 1.13 & 2.98 & 21 \\
\hline GPCC-S1 & 44.00 & 0.52 & 2.81 & 22 \\
\hline GPCC-S2 & 63.71 & 0.75 & 2.73 & 19 \\
\hline GPCC-S3 & 94.46 & 1.13 & 2.61 & 18 \\
\hline \multicolumn{5}{|c|}{ Doubly reinforced beam (DRB) } \\
\hline GPCSC-D1 & 119.15 & 2.01 & 3.02 & 53 \\
\hline GPCSC-D2 & 120.75 & 3.14 & 2.45 & 49 \\
\hline GPCSC-D3 & 126.73 & 3.89 & 1.98 & 48 \\
\hline GPCC-D1 & 114.93 & 2.01 & 2.64 & 50 \\
\hline GPCC-D2 & 115.18 & 3.14 & 2.42 & 46 \\
\hline GPCC-D3 & 118.54 & 3.89 & 1.45 & 38 \\
\hline
\end{tabular}

$A_{\mathrm{st}}$ : area of reinforcement; $b$ : breadth of beam; $d$ : effective depth of a beam.

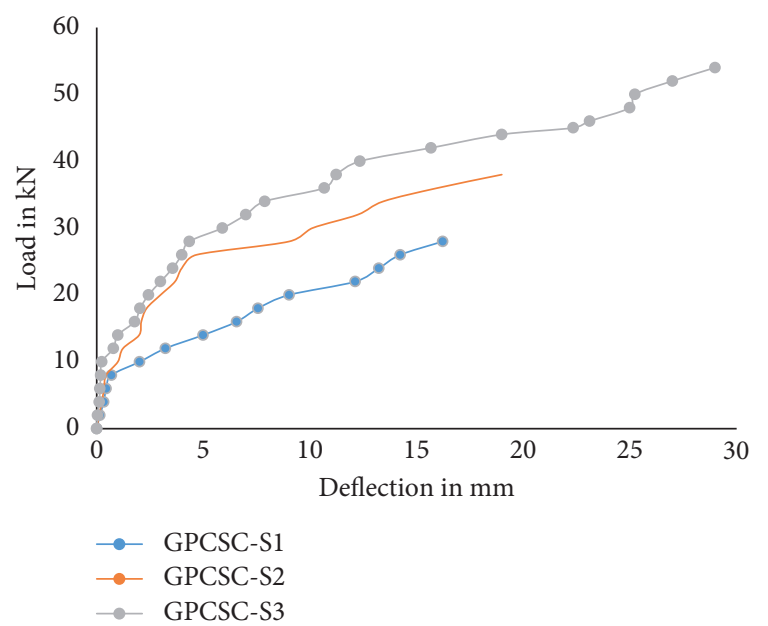

FIgURE 11: Load-deflection behaviour of GPCSC (SRB).

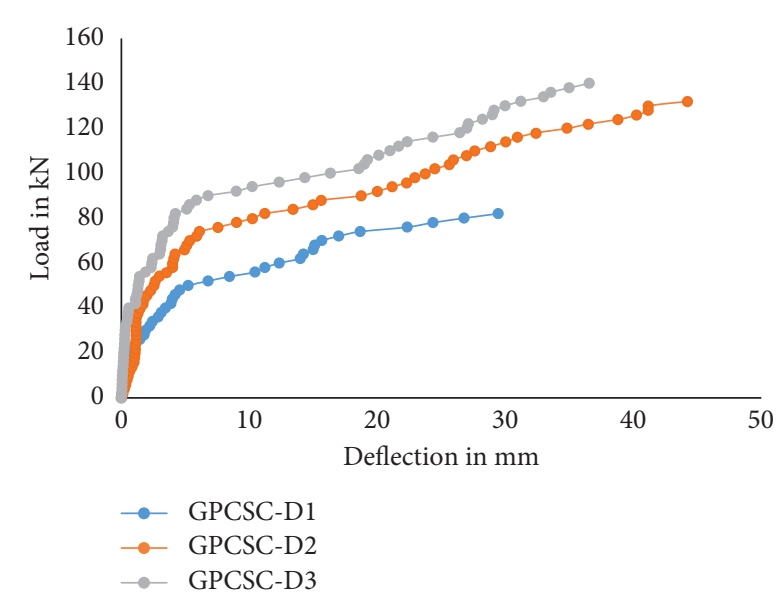

Figure 12: Load-deflection behaviour of GPCSC (DRB).

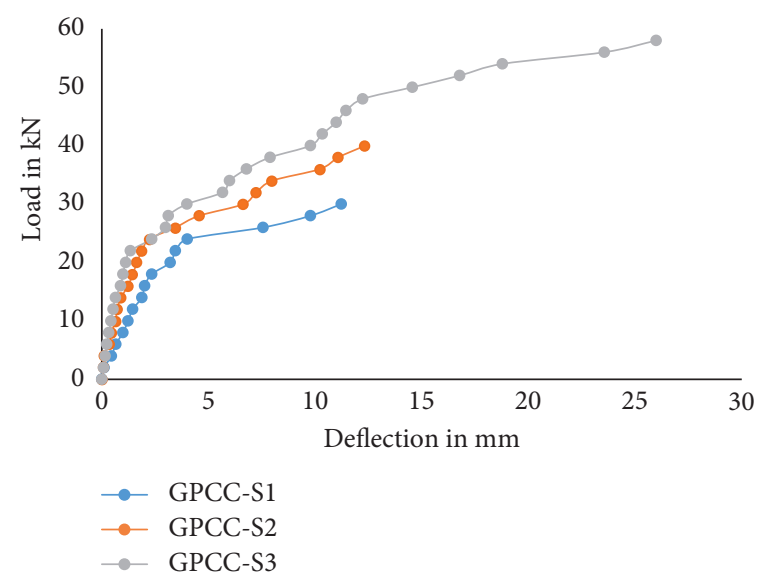

FIGURE 13: Load-deflection behaviour of GPCC (SRB).

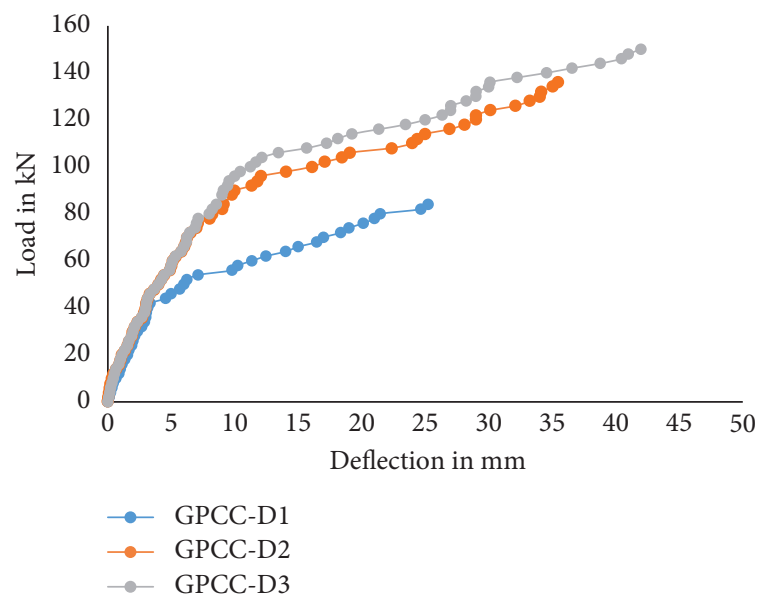

FIGURE 14: Load-deflection behaviour of GPCC (DRB). 
TABLE 6: Comparison of test results at service stage and ultimate stage.

\begin{tabular}{|c|c|c|c|c|c|c|c|c|}
\hline Beam ID & $\begin{array}{c}\text { Service } \\
\text { load }(\mathrm{kN})\end{array}$ & $\begin{array}{l}\text { Ultimate } \\
\text { load }(\mathrm{kN})\end{array}$ & $\begin{array}{l}\text { 1st crack } \\
\text { load }(\mathrm{kN})\end{array}$ & $\begin{array}{c}\text { Cracking } \\
\text { moment }(\mathrm{mcr}- \\
\exp )(\mathrm{kN} \cdot \mathrm{m})\end{array}$ & $\begin{array}{c}\text { Service moment } \\
\left(M_{\mathrm{s}}-\mathrm{exp}\right) \\
(\mathrm{kN} \cdot \mathrm{m})\end{array}$ & $\begin{array}{c}\text { Ultimate } \\
\text { moment }\left(\mathrm{M}_{u^{-}}\right. \\
\exp )(\mathrm{kN} \cdot \mathrm{m})\end{array}$ & $\begin{array}{c}\text { Ultimate } \\
\text { moment }\left(M_{u^{-}}\right. \\
\text {theo })(\mathrm{kN} \cdot \mathrm{m})\end{array}$ & $\begin{array}{c}\text { Capacity } \\
\text { ratio }\end{array}$ \\
\hline \multicolumn{9}{|c|}{ Singly reinforced beam } \\
\hline $\begin{array}{l}\text { GPCSC- } \\
\text { S1 }\end{array}$ & 18.67 & 28 & 9 & 4.20 & 8.71 & 13.07 & 12.24 & 1.07 \\
\hline $\begin{array}{l}\text { GPCSC- } \\
\text { S2 }\end{array}$ & 25.33 & 38 & 10 & 4.67 & 11.82 & 17.73 & 16.88 & 1.05 \\
\hline $\begin{array}{l}\text { GPCSC- } \\
\text { S3 }\end{array}$ & 36.00 & 54 & 11 & 5.13 & 16.80 & 25.20 & 22.69 & 1.11 \\
\hline $\begin{array}{l}\text { GPCC- } \\
\text { S1 }\end{array}$ & 20.00 & 30 & 10 & 4.66 & 9.33 & 14.00 & 12.41 & 1.13 \\
\hline $\begin{array}{l}\text { GPCC- } \\
\text { S2 }\end{array}$ & 26.67 & 40 & 12 & 5.60 & 12.45 & 18.67 & 17.17 & 1.09 \\
\hline $\begin{array}{l}\text { GPCC- } \\
\text { S3 }\end{array}$ & 38.67 & 58 & 14 & 6.53 & 18.05 & 27.07 & 23.58 & 1.15 \\
\hline \multicolumn{9}{|c|}{ Doubly reinforced beam } \\
\hline $\begin{array}{l}\text { GPCSC- } \\
\text { D1 }\end{array}$ & 54.67 & 82 & 12 & 5.60 & 25.51 & 38.27 & 35.69 & 1.07 \\
\hline $\begin{array}{l}\text { GPCSC- } \\
\text { D2 }\end{array}$ & 88.00 & 132 & 13 & 6.07 & 41.07 & 61.60 & 59.94 & 1.03 \\
\hline $\begin{array}{l}\text { GPCSC- } \\
\text { D3 }\end{array}$ & 102.67 & 154 & 16 & 7.47 & 47.91 & 71.87 & 73.71 & 0.98 \\
\hline $\begin{array}{l}\text { GPCC- } \\
\text { D1 }\end{array}$ & 56.00 & 84 & 14 & 6.53 & 26.13 & 39.20 & 37.65 & 1.04 \\
\hline $\begin{array}{l}\text { GPCC- } \\
\text { D2 }\end{array}$ & 90.67 & 136 & 15 & 7.00 & 42.31 & 63.47 & 61.59 & 1.03 \\
\hline $\begin{array}{l}\text { GPCC- } \\
\text { D3 }\end{array}$ & 108.00 & 162 & 18 & 8.40 & 50.40 & 75.60 & 75.07 & 1.01 \\
\hline
\end{tabular}

TABLE 7: Comparison of the capacity ratio of LWC with others.

\begin{tabular}{lcccc}
\hline Coarse aggregate & Code & Mean & Standard deviation & Author \\
\hline Coconut shell (full replacement) & IS 456 [20] & 1.26 & 0.048 & Current study \\
Coconut shell (partial replacement) & IS 456 [20] & 1.35 & 0.049 & Parkash et al. [14] \\
Coconut shell (full replacement) & IS 456 [20] & 1.09 & 0.000 & Parkash et al. [14] \\
Coconut shell & IS 456 [20] & 1.19 & 0.148 & Gunasekaran et al. [10] \\
Oil palm shell & BS8110 [34] & 1.16 & 0.115 & Teo et al. [35, 36] \\
\hline
\end{tabular}

TABle 8: Deflection at service stage and ultimate stage.

\begin{tabular}{|c|c|c|c|c|c|}
\hline \multirow[b]{2}{*}{ Beam ID } & \multicolumn{2}{|c|}{ Service stage } & \multicolumn{2}{|c|}{ Ultimate stage } & \multirow{2}{*}{$\begin{array}{l}\text { Ductility index } \\
\qquad\left(\Delta_{U}\right) /\left(\Delta_{Y}\right)\end{array}$} \\
\hline & Load $(\mathrm{kN})$ & $\begin{array}{c}\text { Displacement } \\
(\Delta y)(\mathrm{mm})\end{array}$ & Load $(\mathrm{kN})$ & $\begin{array}{c}\text { Displacement } \\
(\Delta u)(\mathrm{mm})\end{array}$ & \\
\hline \multicolumn{6}{|c|}{ Singly reinforcement beam } \\
\hline GPCSC-S1 & 18.67 & 7.56 & 28 & 16.82 & 2.22 \\
\hline GPCSC-S2 & 25.33 & 9.02 & 38 & 18.99 & 2.11 \\
\hline GPCSC-S3 & 36.00 & 10.67 & 54 & 28.99 & 2.72 \\
\hline GPCC-S1 & 20.00 & 3.21 & 30 & 11.23 & 3.50 \\
\hline GPCC-S2 & 26.67 & 3.45 & 40 & 12.34 & 3.58 \\
\hline GPCC-S3 & 38.67 & 7.89 & 58 & 25.99 & 3.29 \\
\hline \multicolumn{6}{|c|}{ Doubly reinforcement beam } \\
\hline GPCSC-D1 & 54.67 & 10.45 & 82 & 29.45 & 2.82 \\
\hline GPCSC-D2 & 88.00 & 15.67 & 132 & 43.44 & 2.77 \\
\hline GPCSC-D3 & 102.67 & 18.56 & 154 & 53.45 & 2.88 \\
\hline GPCC-D1 & 56.00 & 7.11 & 84 & 25.22 & 3.55 \\
\hline GPCC-D2 & 90.67 & 9.99 & 136 & 35.45 & 3.55 \\
\hline GPCC-D3 & 108.00 & 15.66 & 162 & 45.45 & 2.90 \\
\hline
\end{tabular}


TABle 9: Comparison of deflection with the Indian standard code.

\begin{tabular}{|c|c|c|c|c|}
\hline Beam ID & Experimental deflection $(\Delta \exp )$ & Permissible deflection ( $\Delta$ per) as per IS465-2000 & $(\Delta \exp ) /(\Delta$ per $)$ & $\overline{\operatorname{Span}(\Delta \exp )}$ \\
\hline \multicolumn{5}{|c|}{ Singly reinforcement beam } \\
\hline GPCSC-S1 & 16.82 & 11.67 & 1.44 & 166.47 \\
\hline GPCSC-S2 & 18.99 & 11.67 & 1.63 & 147.45 \\
\hline GPCSC-S3 & 28.99 & 11.67 & 2.48 & 96.59 \\
\hline GPCC-S1 & 11.87 & 11.67 & 0.96 & 235.89 \\
\hline GPCC-S2 & 12.34 & 11.67 & 1.06 & 226.90 \\
\hline GPCC-S3 & 25.99 & 11.67 & 2.23 & 107.73 \\
\hline \multicolumn{5}{|c|}{ Doubly reinforcement beam } \\
\hline GPCSC-D1 & 29.45 & 11.67 & 2.52 & 95.08 \\
\hline GPCSC-D2 & 43.44 & 11.67 & 3.72 & 64.46 \\
\hline GPCSC-D3 & 53.45 & 11.67 & 4.58 & 52.39 \\
\hline GPCC-D1 & 25.22 & 11.67 & 2.16 & 111.02 \\
\hline GPCC-D2 & 35.45 & 11.67 & 3.04 & 78.98 \\
\hline GPCC-D3 & 45.45 & 11.67 & 3.89 & 61.61 \\
\hline
\end{tabular}

permissible limits of some other standards or else study should be taken in the future to establish the control deflection for both GPCC and GPCSC beams under flexure.

3.5. Ductility Behaviour. The ratio of total deflection at ultimate load to the deflection at service load is known as the ductility index. The ductility indices of all the beams tested are presented in Table 8. Since coconut shell aggregate possesses good toughness and shock absorbance [10], it contributes to improving the ductility index in all the beams. In this study, the ductility indices vary from 2.11 to 2.88 for GPCSC and from 2.90 to 3.59 for GPCC. The lowest value is recorded in beam GPCSC-S2 and the highest value is recorded in beam GPCC-S2. Similar results have also been reported in previous research $[33,34]$.

3.6. Strain Measurement. The main objective of measuring the strain on the longitudinal steel bar is to find whether the beam reaches the yielding point during the test. The steel strain was measured with strain gauges attached to the tension steel bar. The concrete compressive strain was measured with strain gauges attached in the compression zone (Figures 2 and 3).

3.6.1. Steel Bar in Tensile and Concrete in the Compression Zone (SRB). The actual moment-strain behaviour of singly reinforced beam for GPCSC and GPCC is given in Figures 15 and 16. It can be seen that the load-strain curvature pattern is similar in both GPCC and GPCSC beams and it also happens in both bottom tensile reinforcement in the tension zone and geopolymer concrete in the compression zone. The strain in the tensile reinforcement at the ultimate stage was SRB S1-3987 $\mu \mathrm{m}, \mathrm{SRB}$ S2-4447 $\mu \mathrm{m}$, and SRB S3$4823 \mu \mathrm{m}$ for GPCSC. Also, the strain in the geopolymer concrete in the compression zone at the ultimate stage was SRB S1-2565 $\mu \mathrm{m}$, SRB S2-3656 $\mu \mathrm{m}$, and SRB S3-4565 $\mu \mathrm{m}$ for GPCSC. Similarly, the strain in the tensile reinforcement at the ultimate stage was SRB S1-2343 $\mu \mathrm{m}$, SRB S2-267 $5 \mu \mathrm{m}$, and SRB S3-4213 $\mu \mathrm{m}$ for GPCC. Also, the strain in the geopolymer concrete in the compression zone at the

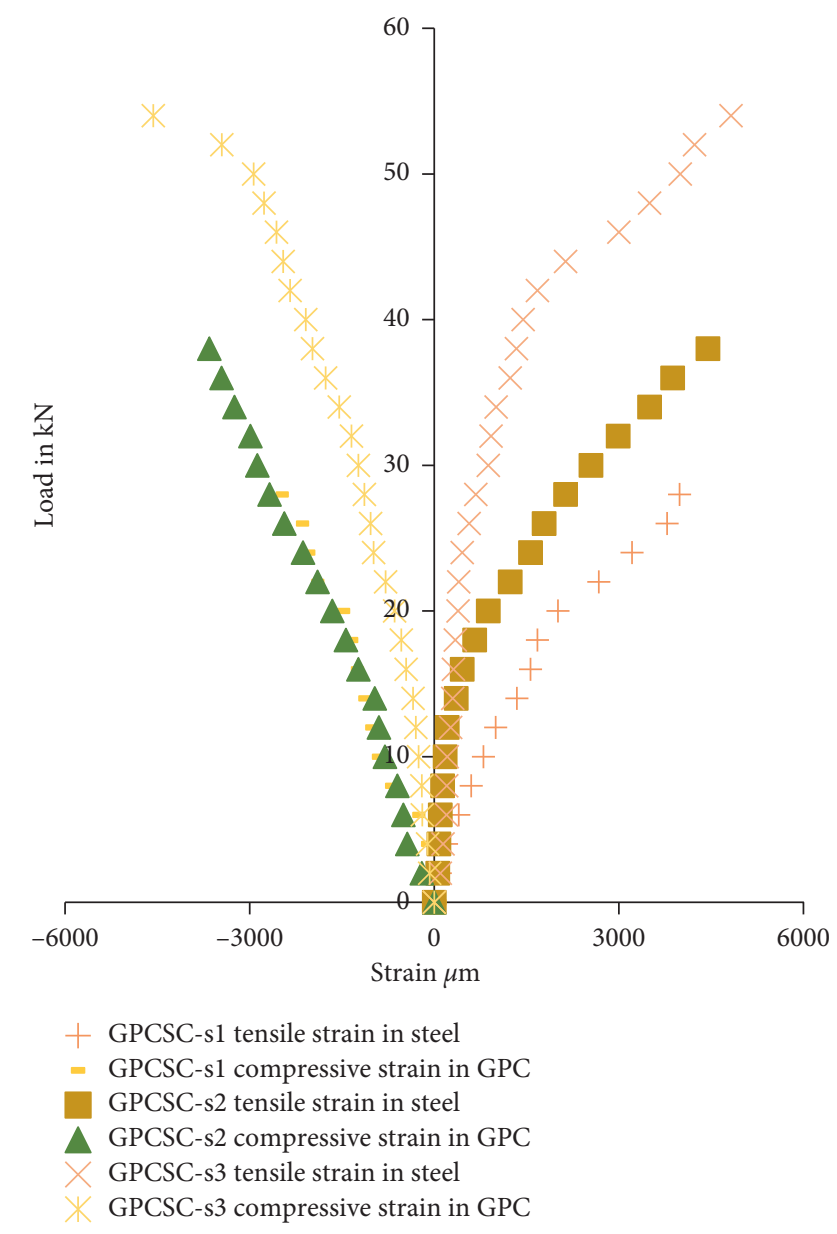

FIGURE 15: Load-strain behaviour of GPCSC (SRB).

ultimate stage was SRB S1-1897 $\mu \mathrm{m}$, SRB S2-2008 $\mu \mathrm{m}$, and SRB S3-3012 $\mu \mathrm{m}$ for GPCC.

The tested beam specimens of SRB shared almost the same small increase of linear strain segment in both GPCSC and GPCC beams until initial crack load. A linear and nonlinear increase in strain was observed beyond the initial crack load. The failure mode of GPCSC beams is akin to GPCC beams and also GPCSC beams achieved their 


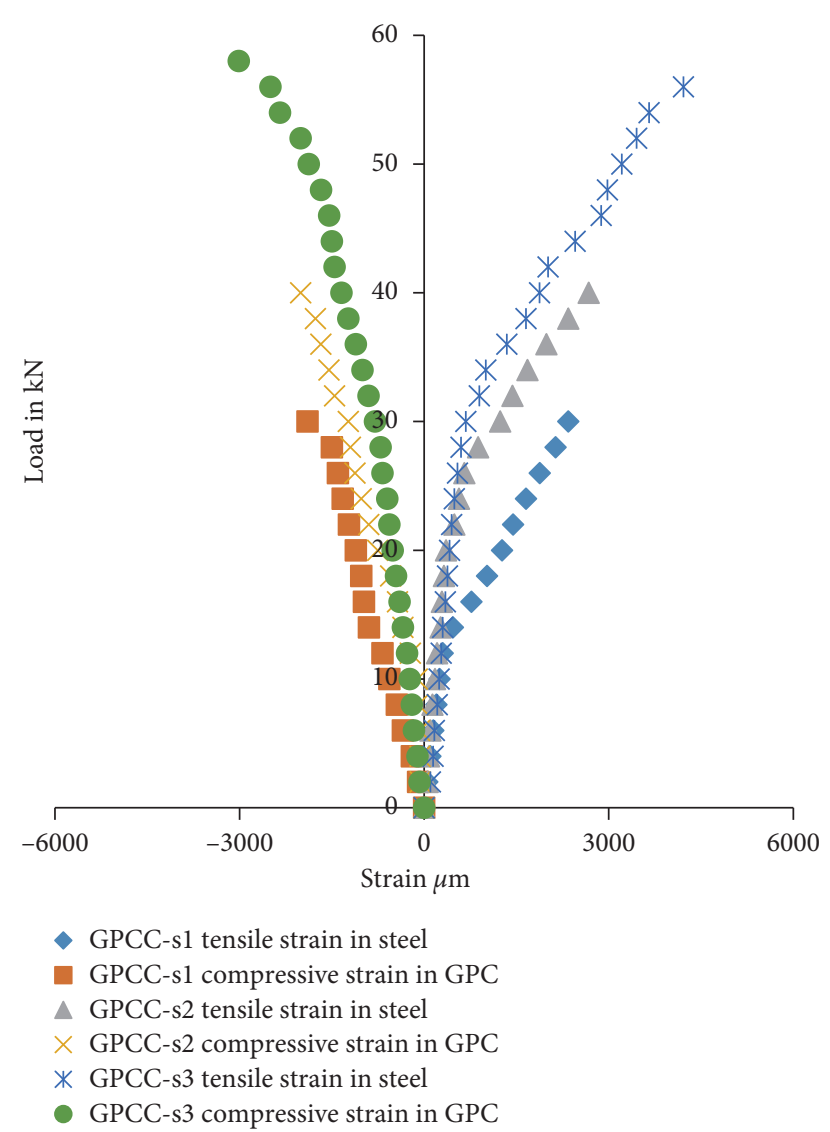

FIgURE 16: Load-strain behaviour of GPCC (SRB).

maximum strain like GPCC. Therefore, it can be stated that the GPCSC beam behaviour is concurrent with the GPCC beams. For GPCSC-S1 and GPCSC-S2, the strain in tensionsteel bars is less than the strains in GPCC which indicates a tension failure mode because in both the cases the same amount of steel was provided but GPCSC steels strains are less due to less CSC strength compatibility compared to CC strength and hence tension failure happens. For GPCSC-S3 beam, the strain in concrete is almost equal to the ultimate strain in steel, which indicates a balanced failure mode; i.e., in this case, concrete and steel strains almost reach simultaneously. But, for GPCC-S1, S2, and S3, the strain in tension-steel bars is less than the strains in geopolymer concrete, indicating a tension failure mode. Overall, the effect of the process of crack formation can be noticed on the moment-strain curves in both singly reinforced geopolymer beams.

3.6.2. Steel Bar in Tensile and Concrete in the Compression Zone (DRB). The actual moment-strain behaviour of a doubly reinforced beam for GPCSC and GPCC is given in Figures 17 and 18. Load-strain curvature observed among the bottom tensile reinforcement in tension zone, geopolymer concrete, and compression reinforcement in

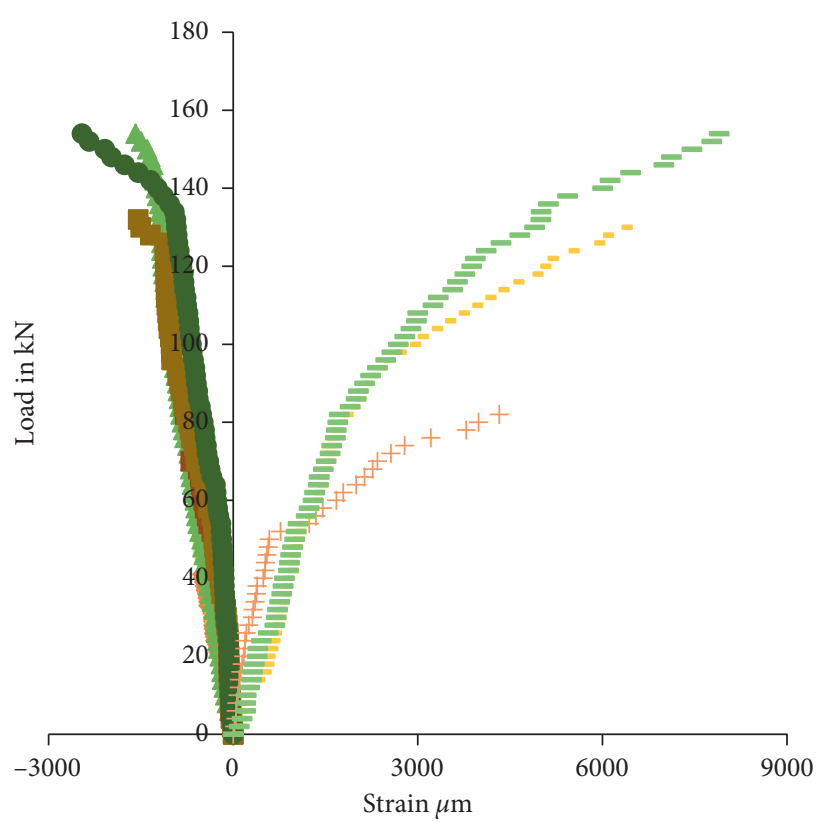

- GPCSC-d1 compressive strain in steel

- GPCSC-d2 compressive strain in steel

$\triangle$ GPCSC-d3 compressive strain in steel

- GPCSC-d1 compressive strain in GPC

- GPCSC-d2 compressive strain GPC

- GPCSC-d3 compressive strain in GPC

- GPCSC-d1 tensile strain in steel

- GPCSC-d2 tensile strain in steel

- GPCSC-d3 tensile strain in steel

FIGURE 17: Load-strain behaviour of GPCSC (DRB).

compression zone is analogous in both GPCSC and GPCC. The strain in the tensile loading at the ultimate stage was DRB D1-4323 $\mu \mathrm{m}$, DRB D2-6678 $\mu \mathrm{m}$, and DRB D3-7898 $\mu \mathrm{m}$ for GPCSC. Similarly, the strain in the tensile reinforcement at the ultimate stage was: DRB D1-3676 $\mu \mathrm{m}, \mathrm{DRB}$ D2-5004 $\mu \mathrm{m}$, and DRB D3-5976 $\mu \mathrm{m}$ for GPCC. The strain in the compression reinforcement and compression zone concrete for GPCSC at the ultimate stage was: DRB D1$498 \mu \mathrm{m}$ and $777 \mu \mathrm{m}, \mathrm{DRB} \mathrm{D} 2-1545 \mu \mathrm{m}$ and $1100 \mu \mathrm{m}$, and DRB D3-2457 $\mu \mathrm{m}$ and $1586 \mu \mathrm{m}$, respectively. The strain in the compression reinforcement and compression zone concrete for GPCC at the ultimate stage was DRB D1$400 \mu \mathrm{m}$ and $678 \mu \mathrm{m}, \mathrm{DRB} \mathrm{D} 2-856 \mu \mathrm{m}$ and $1009 \mu \mathrm{m}$, and DRB D3-1408 $\mu \mathrm{m}$ and $1678 \mu \mathrm{m}$, respectively. All the geopolymer beams were subjected to ductile failure with an increased strain percentage in GPCC when compared to GPCSC. The tested beam specimens of a doubly reinforced beam shared almost the same small linear increase in strain segment in both GPCSC and GPCC beam until initial crack load. A rapid increase of linear and nonlinear strain was observed beyond the initial crack load. All doubly reinforced geopolymer beams (GPCSC-D1, D2, and D3 and GPCC-D1, D2, and D3) show a tension mode failure where the strain in the tension steel bars was greater than that of the strain in 


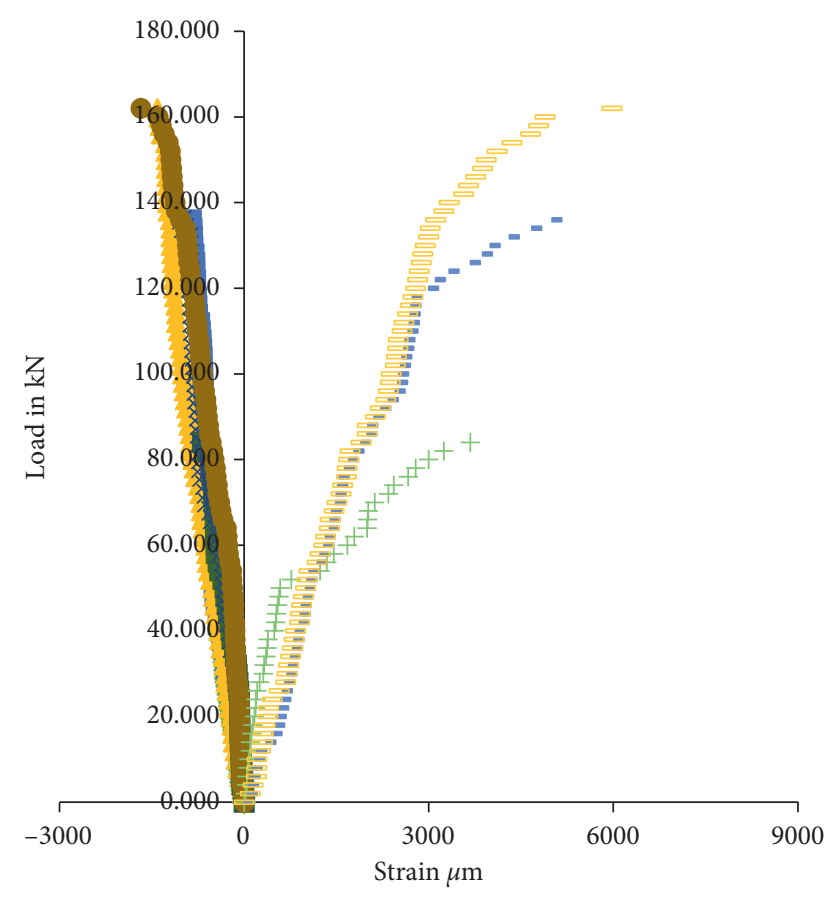

- GPCC-d1 compressive strain in steel

- GPCC-d2 compressive strain in steel

$\triangle$ GPCC-d3 compressive strain in steel

- GPCC-d1 compressive strain in GPC

* GPCC-d2 compressive strain in GPC

- GPCC-d3 compressive strain in GPC

+ GPCC-d1 tensile strain in steel

- GPCC-d2 tensile strain in steel

- GPCC-d3 tensile strain in steel

FIGURE 18: Load-strain behaviour of GPCC (DRB).

geopolymer concrete and compression steel. Overall, the effect of the process of crack formation can be noticed on the moment-strain curves in both geopolymer DRBs.

3.6.3. End Rotation. The end rotation of all geopolymer beams is given in Figures 19 (SRB) and 20 (DRB). GPCSC is subjected to a larger rotation when compared to GPCC. The moment rotation curve follows a linear behaviour up to the yield point and beyond that, there was a rapid increase in rotation. The obtained results are consistent with the work of the other researchers. The end rotation curvature pattern of GPCSC is similar to GPCC, and also they are conservative with the similar work carried out using coconut shell concrete [10].

There are some advantages and disadvantages of the GPCSC mix compared to the GPCC mix. The advantage is GPCSC density is less compared to GPCC because of coconut shell density $\left(550-650 \mathrm{~kg} / \mathrm{m}^{3}\right)$ compared to the conventional stone aggregate density $\left(1600-1800 \mathrm{~kg} / \mathrm{m}^{3}\right)$. Also, due to the fibrous nature of coconut shell aggregate compared to conventional stone aggregate, naturally, the ductility of GPCSC is more compared to GPCC and it is more advantageous especially in the case of seismic resistance. A disadvantage of using coconut shells in urban areas is transportation cost. Therefore, it is most advantageous that

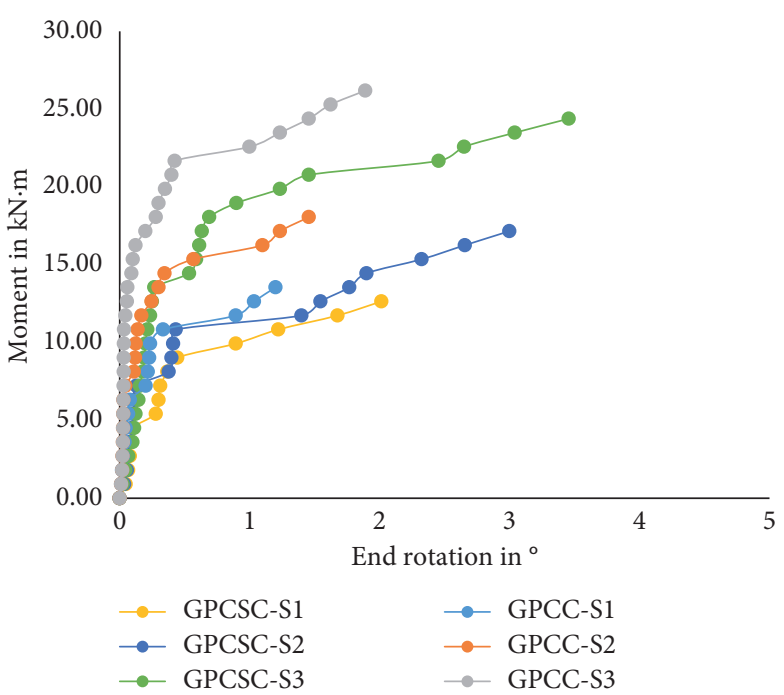

Figure 19: End rotation of SRB.

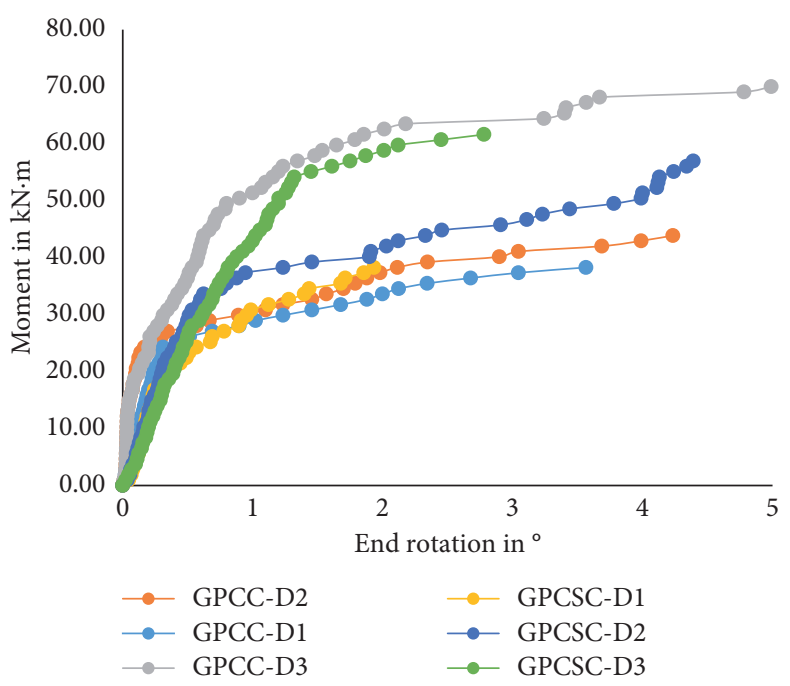

FIgURE 20: End rotation of DRB.

the coconut shell is used in rural areas where it is dumped as waste.

\section{Conclusions}

The methods reviewed in this article demonstrate that it is possible to obtain crushed coconut shell as an effective replacement of coarse aggregate and ground granulated blast furnace slag can be completely used as a replacement for conventional OPC to produce lightweight geopolymer concrete.

Based on the experimental results, the following conclusions were made:

(i) The comparative assessment clearly shows the competitiveness between lightweight geopolymer coconut shell concrete (GPCSC) and geopolymer conventional concrete (GPCC) systems from an environmental point of view. 
(ii) The superior properties of GPCSC demonstrate a promising perspective for the concrete industry in the future. The highest compressive strength of about $32.60 \mathrm{MPa}$ was achieved at 28 days for the mix with $100 \%$ CS replacement as coarse aggregate and it is mainly based on the binder, molarity, alkaline binder ratio, and alkaline activator used in the GPCSC mix.

(iii) The hardened density of GPCSC was found to be $1980 \mathrm{~kg} / \mathrm{m}^{3}$, satisfying the criteria of lightweight aggregate concrete.

(iv) Nearly similar cracking pattern, load-deflection behaviour, the ultimate moment of resistance, deflection capacities, end rotation of the beam, and strain readings were obtained from all the geopolymer tested beams.

(v) The cracked response of the beams at the initial stage was relatively comparable since the strength of the beam depends on the geopolymer concrete strength.

(vi) The increase in reinforcement ratio had a significant effect on first cracking load and ultimate load, for both GPCSC and GPCC beams.

(vii) Beams with lower reinforcement ratios (both SRB and DRB) experienced a fewer number of cracks and a higher value of crack width for GPCSC and GPCC beam, while the beams with higher reinforcement ratio (both SRB and DRB) experienced numerous cracks and less value of crack width. But the number and width of the crack of GPCSC were larger when compared with GPCC for both singly reinforced and doubly reinforced geopolymer beams. The average increase in crack width was $31 \%$ for singly reinforced and $12 \%$ doubly reinforced geopolymer coconut shell concrete beam (GPCSC) when compared with geopolymer conventional concrete beam (GPCC).

(viii) The measured maximum deflections of beams underestimate the predicted deflections by calculation using the provisions of IS 456:2000 and conventional RC theory shows fair agreement but call for improved prediction for geopolymer beams.

(ix) The experimental moment is compared with the theoretical moment calculated using the stress block analysis of IS 456:2000 and found to be 3\% to $15 \%$ higher than the theoretical moment. The experimental moment capacity of the GPCC beams investigated in the study was found to be more than that of the GPCSC beams because of their higher compressive strength.

(x) The ultimate moment carrying capacity of the test beams calculated using the conventional reinforced concrete principles and strain compatibility approach showed a good correlation between the test and calculated values as per codal provision. The studies showed that the computational methods used for evaluating the performance parameters of the conventional concrete beams at different stages can also be extended to geopolymer beams.

(xi) The ductility index of all the geopolymer concrete beams is found to be in the range of 2.11 to 3.58 , due to good ductility behaviour and it provides sufficient warning before failure. It reveals that both GPCSC and GPCC have good toughness characteristics.

(xii) Both single and doubly reinforced geopolymer beans (GPCSC and GPCC) undergo failure by the yielding of steel reinforcement in the tension zone, followed by crushing of concrete in the compression zone. A large deflection is observed in all GPCSC which indicates that the coconut shell concrete fails in a ductile manner.

(xiii) The end rotation of the GPCSC beams investigated in the study was found to be more than that of the GPCC beams because of the good flexural behaviour of coconut shell concrete.

Overall, the geopolymer coconut shell concrete with GGBS is suitable to be utilized as a sustainable eco-friendly construction material as the coconut shell is a renewable and naturally available resource, while GGBS is an industrial waste.

\section{Data Availability}

All data used to support this study are included within the article.

\section{Conflicts of Interest}

The authors declare no conflicts of interest.

\section{Authors' Contributions}

K. Gunasekaran and S. Nithya contributed to conceptualization; S. Nithya contributed to methodology, investigation, and original draft preparation; K. Gunasekaran and G. Sankar contributed to review and editing and supervision. All authors have read and agreed on the published version of the manuscript.

\section{Acknowledgments}

The authors thank the SRM Institute of Science and Technology for their support in completing this study and those who were directly or indirectly involved in this study. Also, the authors express their thanks to the Nano Technology 
Research Centre, SRM Institute of Science and Technology, for their help with microanalysis.

\section{References}

[1] R. M. Andrew, "Global CO2 emissions from cement production," Earth System Science Data, vol. 10, no. 1, pp. 195-217, 2018.

[2] J. Davidovits, "Mineral polymers and method of making them," The United States Patent, vol. 4, pp. 349-386, 1982.

[3] J. Davidovits, "Geopolymers," Journal of Thermal Analysis, vol. 37, no. 8, pp. 1633-1656, 1991.

[4] B. Li, G. Ke, and M. Zhou, "Influence of manufactured sand characteristics on strength and abrasion resistance of pavement cement concrete," Construction and Building Materials, vol. 25, no. 10, pp. 3849-3853, 2011.

[5] A. Islam, U. J. Alengaram, M. Z. Jumaat, and I. I. Bashar, "The development of compressive strength of ground granulated blast furnace slag-palm oil fuel ash-fly ash based geopolymer mortar," Materials \& Design (1980-2015), vol. 56, pp. 833-841, 2014.

[6] A. Jayaprithika and S. K. Sekar, "Stress-strain characteristics and flexural behaviour of reinforced Eco-friendly coconut shell concreteflexural behaviour of reinforced Eco-friendly coconut shell concrete," Construction and Building Materials, vol. 117, pp. 244-250, 2016.

[7] A. Jaya prithika and S. K. Sekar, "Mechanical and fracture characteristics of Eco-friendly concrete produced using coconut shell, ground granulated blast furnace slag and manufactured sand," Construction and Building Materials, vol. 103, pp. 1-7, 2016.

[8] S. Nithya, N. S. Elangovan, and G. Sankar, "Renewable waste coconut shell as lightweight aggregate in concrete: a review," Interciencia Journal, vol. 44, no. 12, pp. 286-321, 2019.

[9] S. Nithya, N. S. Elangovan, and G. Sankar, "Mechanical and microstructural properties of coconut shell based lightweight geopolymer concrete blended with ground granulated blast furnace slag," Interciencia journal, vol. 45, no. 2, pp. 94-128, 2020.

[10] K. Gunasekaran, R. Annadurai, and P. S. Kumar, "Study on reinforced lightweight coconut shell concrete beam behavior under flexure," Materials \& Design, vol. 46, pp. 157-167, 2013b.

[11] A. Jayaprithika, Experimental Study on Eco-Friendly concrete with Coconut Shell, Blast Furnace Slag and Manufactured Sand, Ph.D. thesis, Vellore Institute of Technology, Vellore, India, 2016.

[12] E. A. Olanipekun, K. O. Olusola, and O. Ata, "A comparative study of concrete properties using coconut shell and palm kernel shell as coarse aggregates," Building and Environment, vol. 41, no. 3, pp. 297-301, 2006.

[13] A. Yerramala and C. Ramachandrudu, "Properties of concrete with coconut shells as an aggregate replacement," International Journal of Engineering and Inventions, vol. 1, pp. 21-31, 2012.

[14] R. Prakaah, R. Thenmozhi, and S. N. Ramanan, "Mechanical characterisation and flexural performance of eco-friendly concrete produced with fly ash as cement replacement and coconut shell coarse aggregate," International Journal of Environment and Sustainable Development, vol. 18, no. 2, pp. 131-147, 2019.

[15] S. U. Azunna, F. N. A. A. Aziz, N. Abu Bakar, and A. Mohd Nasir, "Mechanical properties of concrete with coconut shell as partial replacement of aggregates," in Proceedings of the IOP
Conference Series: Materials Science and Engineering, vol. 431, November 2018.

[16] BIS, IS 383: 2016, Indian Standard for Specification for Coarse and Fine Aggregates from Natural Sources for Concrete, Bureau of Indian Standard, New Delhi, India, 2016.

[17] Standard Specification for Standard Sand, ASTM C778-17.

[18] "Standard practice for selecting proportions for structural lightweight," ACI, vol. 211, pp. 2-98.

[19] ASTM C127-15 Standard Test Method for Relative, Density (Specific Gravity) and Absorption of Coarse Aggregate, ASTM, West Conshohocken, PA, US.

[20] BIS, IS 456:2000, Indian Standard plain and Reinforced concrete-code of Practice, Bureau of Indian standards, New Delhi, India.

[21] IS 516, Indian Standard Code of Practice for Method of Tests for Strength of concrete, Bureau of Indian Standard, New Delhi; India, 1959.

[22] ASTM C496-90, Standard Test Method for Splitting Tensile Strength of Cylindrical concrete Specimens: Annual Book of ASTM Standards, ASTM, West Conshohocken, PA, US.

[23] ASTM, C78-84. Standard Test Method for Flexural Strength of concrete: Annual Book of ASTM Standards, ASTM, West Conshohocken, PA, US.

[24] ASTM C469-02, "Standard test method for static modulus of elasticity and Poisson's ratio of concrete in compression," American Society for Testing and Materials B, vol. 4, pp. 1-5, 2002.

[25] IS 1786, High Strength Deformed Steel Bars and Wires for concrete Reinforcement, Bureau of Indian Standard, New Delhi; India, 2008.

[26] ASTM, C171-16. Standard Specification for Sheet Materials for Curing Concrete, ASTM International, West Conshohocken; PA USA, 2016.

[27] U. J. Alengaram, M. Z. Jumaat, and H. Mahmud, "Ductility behaviour of reinforced palm kernel shell concrete beams," European Journal of Scientific Research, vol. 23, no. 3, pp. 406-420, 2008.

[28] U. J. Alengaram, K. H. Mo, P. Visintin, and M. Z. Jumaat, "Prediction of the structural behaviour of oil palm shell lightweight concrete beams," Construction and Building Materials, vol. 102, pp. 722-732, 2016.

[29] B. Ginghis, C. Maranan, M. Allan, W. Karunasena, B. Benmokrane, and P. Mendis, "Flexural response of GFRPreinforced geopolymer concrete beams," in Proceedings of the 27th Biennial National Conference of the Concrete Institute of Australia, pp. 287-296, Melbourne, Australia, August 2015a.

[30] B. Ginghis, Maranan, A. C. Manalo, B. Benmokrane, W. Karunasena, and P. Mendis, "Evaluation of the flexural strength and serviceability of geopolymer concrete beams reinforced with glass-fibre-reinforced polymer bars," Engineering Structures, vol. 101, pp. 529-541, 2015b.

[31] D. Y. Yoo, H. O. Shin, K. Y. Kwon, and Y. S. Yoon, "Structural behaviour of UHPFRC beams according to reinforcement ratio of internal GFRP bar," in Proceedings of the The 7th International Conference on FRP Composites in Civil Engineering (CICE 2014), R. El-Haacha, Ed., International Institute for FRP in Construction (IIFC), Vancouver, Canada, August 2014.

[32] H. Q. Ahmed, D. K. Jaf, and S. A. Yaseen, "Comparison of the flexural performance and behaviour of fly-ash-based geopolymer concrete beams reinforced with CFRP and GFRP bars," Advances in Materials Science and Engineering, vol. 2020, Article ID 3495276, 15 pages, 2020. 
[33] J. K. Dattatreya, N. P. Rajamane, D. Sabitha, P. S. Ambily, and M. C. Nataraja, "Flexural behaviour of reinforced Geopolymer concrete beams," International Journal of Civil and Structural Engineering, vol. 2, no. 1, pp. 138-159, 2011.

[34] Bs 8110, Structural Use of concrete-Part 1: Code of Practice for Design and Construction, British Standard Institution, London.

[35] D. C. L. Teo, M. A. Mannan, V. J. Kurian, and J. V. Kurian, "Flexural behaviour of reinforced lightweight concrete beams made with oil palm shell (OPS)," Journal of Advanced Concrete Technology, vol. 4, no. 3, pp. 459-468, 2006 a.

[36] D. C. L. Teo, M. A. Mannan, and V. J. Kurian, "Structural concrete using oil palm shell (OPS) as lightweight aggregate," Turkish Journal of Engineering and Environmental Sciences, vol. 30, pp. 1-7, 2006b. 